\title{
Çeştepe, a new early Pliocene vertebrate locality in Central Anatolia and its stratigraphic context
}

\section{Çeștepe, une nouvelle localité à vertébrés du Pliocène inférieur d'Anatolie centrale et contexte stratigraphique}

\author{
Sevket Sen ${ }^{\mathrm{a}, *}$, Massimo Delfino $^{\mathrm{b}, \mathrm{c}}$, Nizamettin Kazanci $^{\mathrm{d}}$ \\ a UMR 7207 CNRS, Muséum, UPMC, Centre de Recherches sur la Paléobiodiversité et Paléoenvironnements, 8, rue Buffon, 75005 Paris, France \\ b Dipartimento di Scienze della Terra, Università di Torino, Via T. Valperga Caluso 35, 10125 Torino, Italy \\ c Institut Català de Paleontologia Miguel Crusafont, Universitat Autònoma de Barcelona, Edifici ICTA-ICP, Carrer de les Columnes s/n, Campus de la UAB, \\ Cerdanyola del Vallès, Barcelona 08193, Spain \\ d Ankara University, Geological Engineering Department, Tandoğan, Ankara 06100, Turkey
}

\section{A R T I C L E I N F O}

\section{Article history:}

Received 13 November 2016

Accepted 25 January 2017

Available online $\mathrm{xxx}$

\section{Keywords:}

Lagomorpha

Ochotona

Squamata

Varanus

Early Pliocene

Kazan Basin

Turkey

\begin{abstract}
A B S T R A C T
The new locality of Çeştepe in the Kazan Basin, $45 \mathrm{~km}$ NNW of Ankara, yielded the remains of three species of reptiles (cf. Lacerta sp., Anguinae indet. and Varanus sp.) and an ochotonid lagomorph, Ochotona mediterranensis Suata Alpaslan, 2009. The latter species suggests an early Pliocene age (MN14). The fossil layer is included in the Sinap Formation that delivered abundant remains of Mio-Pliocene mammals in the southern part of the basin, but in the northern part of the basin Çeştepe is currently the unique fossil site. The age assigned by the fauna led to revise the stratigraphy of sedimentary formations in the Çeştepe area, previously confusing because of the various lithostratigraphic unit names and ages given in previous work. The taxa described in this note are still poorly known in Turkey. Varanus has been previously reported from Çalta, a locality $16.3 \mathrm{~km} \mathrm{SW}$ to Çeştepe in the same basin, and O. mediterranensis from Iğdeli in the Sivas Basin. Although represented by a few taxa, the Çeștepe faunule shows Eurasian affinities.

(C) 2017 Elsevier Masson SAS. All rights reserved.
\end{abstract}

\section{R É S U M É}

La nouvelle localité de Çeştepe dans le bassin de Kazan, à $45 \mathrm{~km}$ au NNW d'Ankara, a livré les restes de trois espèces de reptiles (cf. Lacerta sp., Anguinae indet. and Varanus sp.) et d'un lagomorphe ochotonidé, Ochotona mediterranensis Suata Alpaslan, 2009. Cette faune et en particulier la dernière espèce permettent de corréler cette localité au Pliocène inférieur (MN14). La couche fossilifère est incluse dans la Formation de Sinap qui a livré d'abondants restes de mammifères mio-pliocènes dans la partie sud de ce bassin, mais dans la partie nord du bassin, Çeştepe est pour le moment l'unique site fossilifère. L'âge attribué par cette faune a permis de revoir la stratigraphie des formations sédimentaires dans ce secteur du bassin de Kazan, auparavant confuse en raison des noms d'unités lithostratigraphiques et des âges différents dans des travaux antérieurs. Les taxons décrits dans la présente note sont encore mal connus en Turquie. Le genre Varanus n'a été décrit auparavant que du gisement de Çalta au SE du même bassin et $O$. mediterranensis du gisement d'Iğdeli dans le bassin de Sivas. Bien que pauvre, cette faunule montre des affinités eurasiatiques. (c) 2017 Elsevier Masson SAS. Tous droits réservés.

\footnotetext{
* Corresponding author.

E-mail addresses: sevket.sen@mnhn.fr (S. Sen), massimo.delfino@unito.it (M. Delfino), kazanci@eng.ankara.edu.tr (N. Kazanci).
}

\section{Introduction}

Pliocene terrestrial deposits occupy quite large areas in Turkey. However, Pliocene vertebrate localities are rather rare and much less documented. In their zonal subdivision of terrestrial Neogene 
in Turkey, Ünay et al. (2003) suggested four mammalian zones ( $\mathrm{M}$ to $\mathrm{P}$ ) for Pliocene based on rodent assemblages. However, the current state of the knowledge about the Pliocene mammals does not allow the effective use of this subdivision, neither accurate correlations with the MN zonation. The main issue is that the Pliocene mammal faunas of Turkey are still poorly documented and their composition is somewhat different from that of the surrounding regions. For Pliocene of Turkey, the bestdocumented fauna is probably Çalta, at some $50 \mathrm{~km} \mathrm{NW}$ to Ankara, in the same basin as Çeștepe (Sen, 1998a, 1998b). Other Pliocene localities, dispersed in sedimentary basins across all Turkey (Saraç, 2003), are mainly known with their rodent associations, in particular those studied by Ünay and de Bruijn (1998) and Van den Hoek Ostende et al. (2015a, 2015b). The discovery of a new locality at Çeştepe (Kazan Basin) provided opportunity to review stratigraphic correlations in this basin and to document Pliocene reptiles and ochotonid lagomorphs in Turkey. As we will see here below, these groups may provide strong arguments for biochronology and environment if they are welldocumented.

\section{Geological context}

\subsection{Geological context of Central Anatolia and Kazan Basin}

The Çeştepe village and vertebrate fossil locality are situated about $45 \mathrm{~km}$ NNW to the capital Ankara, and $14 \mathrm{~km}$ north of Kazan town in the Kazan Basin, Central Anatolia (Fig. 1). This basin is at the southern margin of the Kizılcahamam Volcanic Province (KVP in Fig. 1A) which covers large areas NW to Ankara and south to the North Anatolian Fault Zone (NAFZ). In previous studies, Neogene sediments of the Kazan region were included in the Beypazarı Basin. As will be seen below, this conception most be reconsidered. The Beypazarı and Kazan basins form, together with the KVP, a geomorphological and climatic transition zone between the central and northern regions of Anatolia (Fig. 1). Semi-arid climate, steppic and rather flat landscapes of the Anatolian plateau, which is between the altitudes of 850-1100 meters, turn northward to a mountainous morphology split by deep valleys and under the regime of the rainy climate of the Black Sea region. This transition zone is known with its great floral and faunal biodiversity, its mixed vegetation dominated by Quercus and Pinus, and also other transition forest type plants (Adıgüzel and Vural, 1995; Uyar and Çetin, 2001). To protect and to set forth such a particular ecology, this region became in 1959 the Soğuksu National Park. The region is renowned for its mineral waters sources, coal quarries and fossil rich beds (e.g., Fig. 1B, spots 1-5) (Ozansoy, 1965; Kasapligil, 1977; Alpagut et al., 1996; Rückert-Ülkümen et al., 2002; Fortelius et al., 2003; Hatipoğlu and Türk, 2009). Due to the richness of its natural resources, the Ministry of Environment intended to declare the Kazan-Kızılcahamam region a geopark (Kazanci et al., 2007; Kazanc1, 2012).

From the Paleozoic onwards, Anatolia played the role of tectonic crossroad in the geological history of the Old World. The most significant rock samples of this history can be seen in the north Central Anatolia, in particular in the Ankara region (Fig. 1). The various global tectonic models on the evolution of Paleotethys and Neotethys have been developed over the rocks of this region (see Tekeli, 1981; Okay and Göncüoglu, 2004; Dilek and Thy, 2006, and references therein). The term and concept of "Melange" were shaped on the rocks of this region (Bailey and McCallien, 1953; Sengör, 2003). The rock units and stratigraphy increase in diversity in the area from Paleozoic onwards, because of the progressive grouping of several tectonic units during the Mesozoic (Sakarya Zone, Istanbul Zone, Taurides, Pontides) on which various sedimentary basins (e.g. Çankırı-Çorum, Beypazarı, Polatli-Haymana,
Tuzgölü Tertiary basins) are developed. The Ankara region forms a kind of node where these tectonic units and sedimentary basins get close to each other and/or imbricated (Fig. 1). To clarify such a complex geological context needs robust stratigraphic, biostratigraphic and any kind of chronological data. Therefore, the Çeştepe fossils are of interest not only in terms of systematics and paleoecology of species they represent, but also for their contribution to understand the geological evolution of the region that is increasingly complex throughout the Neogene.

The Gondwana-Eurasia collision, which gave rise to the Alpine-Himalayan mountain chain, created the framework of the current geography of Anatolia. The Anatolian plate became uplifted during the Neogene, and several large and small basins appeared to receive terrestrial sediments (Fig. 1B). In relation with the collision, extensive volcanic provinces developed in different regions of Anatolia since the early Miocene (e.g. East Anatolian Volcanic Province - EAVP, Cappadocian Volcanic Province - CVP, Kızılcahamam Volcanic Province - KVP) and, as examplified in this study, volcanism impacted terrestrial infill of these Neogene basins (Figs. 1 and 2). Local differences in volcanic, volcano-sedimentary and sedimentary input in these basins produced stratigraphic successions that are heterogeneous and difficult to correlate even inside the same basin. This is particularly true for Neogene deposits of Central Anatolian basins (Tatlı, 1975; Öngür, 1976; Gökten et al., 1988; Türkecan et al., 1991; Duru and Aksay, 2002). The North Anatolian Fault Zone (NAFZ), which is the second longest strike-slip fracture of the world after the San Andreas Fault, is situated a few kilometers north of the study area, and it separates the Eurasian and Anatolian plates (Fig. 1). The occurrence of NAFZ indicates the beginning of the neotectonic period in Anatolia, and it is often considered the source of increasing seismic activity (Sengör et al., 2005; Rojay and Karaca, 2008). After the devastating earthquakes in recent years (Izmit, 1999 and Çankırı, 2000), research on the tectonics and seismic activities largely focused in the KazanKızılcahamam region (Koçyiğit et al., 2001; Karaca, 2004; Toori, 2005; Seyitoğlu et al., 2009; Kahraman, 2014). However, a common problem in almost all studies is frequent lateral lithological changes in terrestrial Neogene units in the region and, consequently, dissimilarities in local stratigraphies (see Erişen and Ünlü, 1976; Erol et al., 1980; Türkecan et al., 1991; Duru and Aksay, 2002; Lunkka et al., 2003). To resolve this complexity needs more fossils for a high-resolution biostratigraphy and/or radiometric dating.

\subsection{Kazan Basin}

South to the North Anatolian Fault (NAF) and Kizılcahamam Volcanic Province (KVP), these are several large basins such as Beypazarı, Çankırı-Çorum and Polatli-Haymana basins, and more southern Tuzgölü and Sivrihisar-Beylikova basins (Fig. 1). These are the remnants of large marine foreland basins, which were formed in late Cretaceous-Paleogene along the southern margin of the Pontide collisional zone (Görür et al., 1998; Dirik and Erol, 2000; Karadenizli et al., 2003). They come into contact in the study area. Consequently, Neogene units north of Ankara and in the Kazan region have been mapped as part of the Beypazarı Neogene Basin in some studies or part of the Çankırı-Çorum Basin in the others (Türkecan et al., 1991; Duru and Aksay, 2002; MTA, 2002). In addition, most studies dealing with the geology of the region, named stratigraphic units regardless of the sedimentary basin in which they are (e.g. Ruprecht, 1956; Tatlı, 1975; Erişen and Ünlü, 1976; Erol et al., 1980; Gökten et al., 1988; Lunkka et al., 2003). This confusing situation is probably due to lithologic similarities of Neogene deposits: Miocene sedimentary units in Central Anatolian basins are mainly lacustrine and floodplain deposits, whereas the Pliocene units are of alluvial and fluvial origin. Moreover, not only the lithologies but also fossil communities display great resemblances 


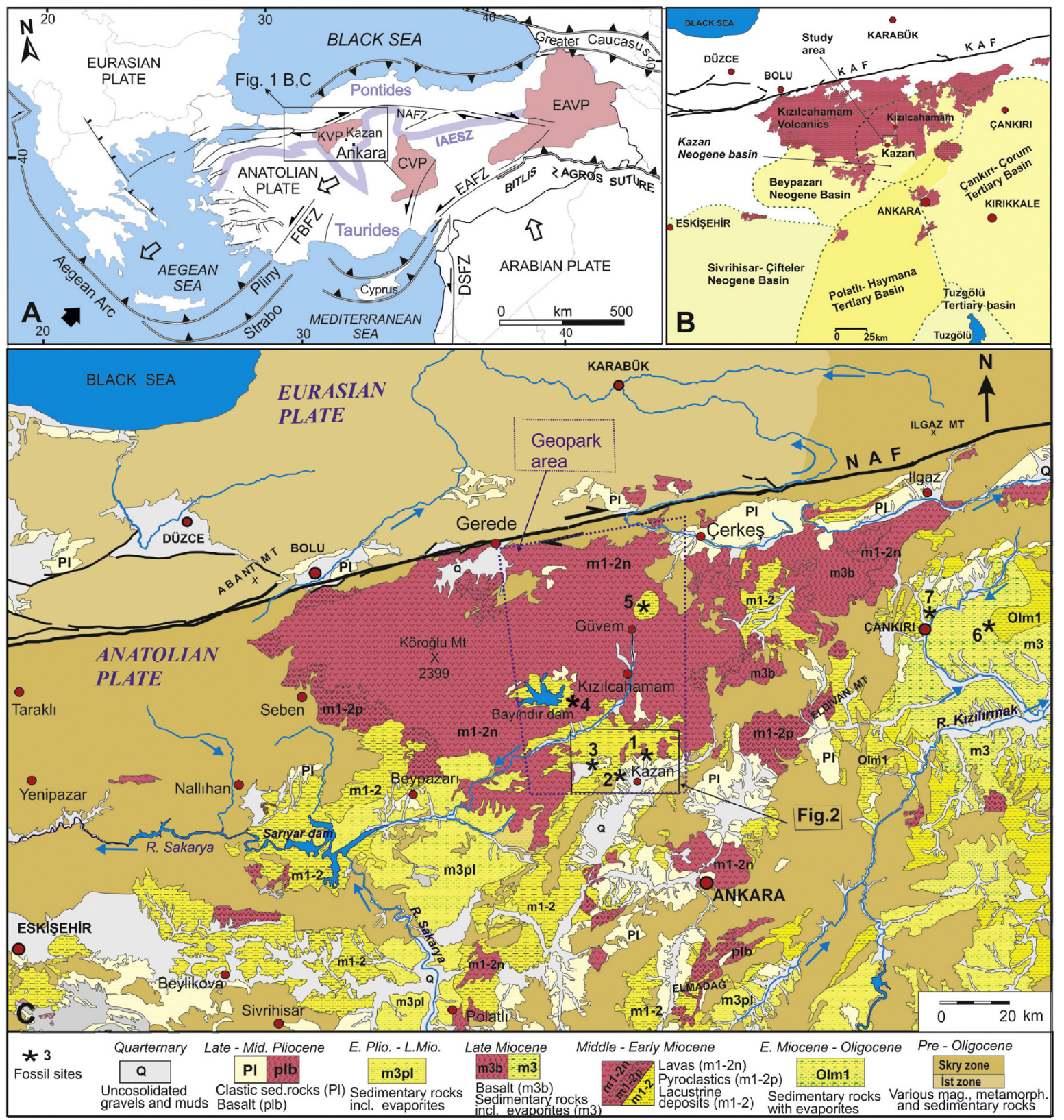

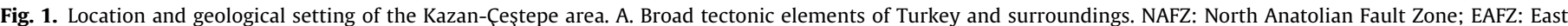

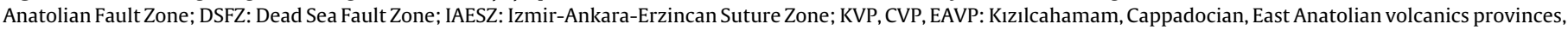

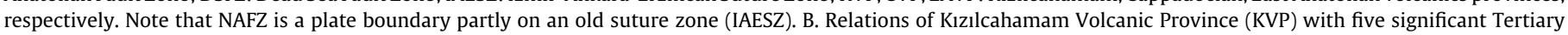

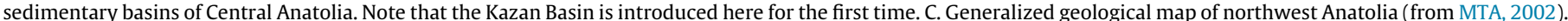

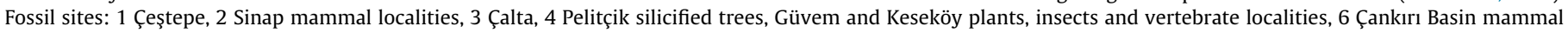
localities, 7 Çorakyerler.

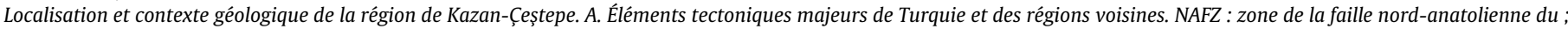

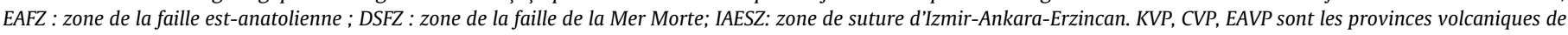

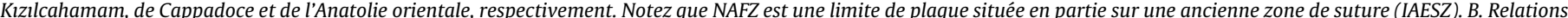

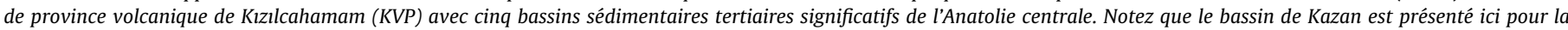

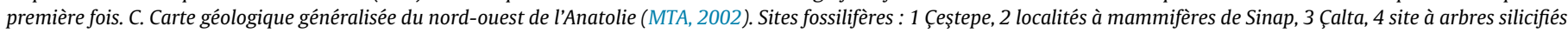
de Pelitçik, 5 site à plantes, insectes et vertébrés fossiles de Güvem et de Keseköy, 6 localités à mammifères du bassin de Çankırı, 7 Çorakyerler.

from one region to another without any kind of endemism (Kazancı et al., 1999; Fortelius et al., 2003; Saraç, 2003). However, when studied in detail, Neogene deposits in the Kazan region are different in their architecture from those of the neighbouring basins. The most important difference is the lack of evaporitic deposits in the Kazan Basin, while they form thick sedimentary units in other basins (Çayirhan Fm and Kirmir Fm in the Beypazari Basin, Bayindir Fm and Bozkir Fm in the Çankırı-Çorum Basin; Inci et al., 1986; Karadenizli, 1995, 2011; Kaymakç1, 2000; Varol et al., 2002). Unlike the other basins, the Kazan Basin has relatively thick Pliocene deposits developed in alluvial fan and meandering river depositional environments. These differences in sedimentary deposits with those of similar age units in the neighbouring basins indicate that the Kazan area functioned as an independent basin during the Neogene. The northern part of this basin is filled with the Kizilcahamam volcanics. It is delimited eastward and westward by the basement rocks (Permo-Triassic, Cretaceous and early Paleogene metamorphic and sedimentary units). The limits of this 


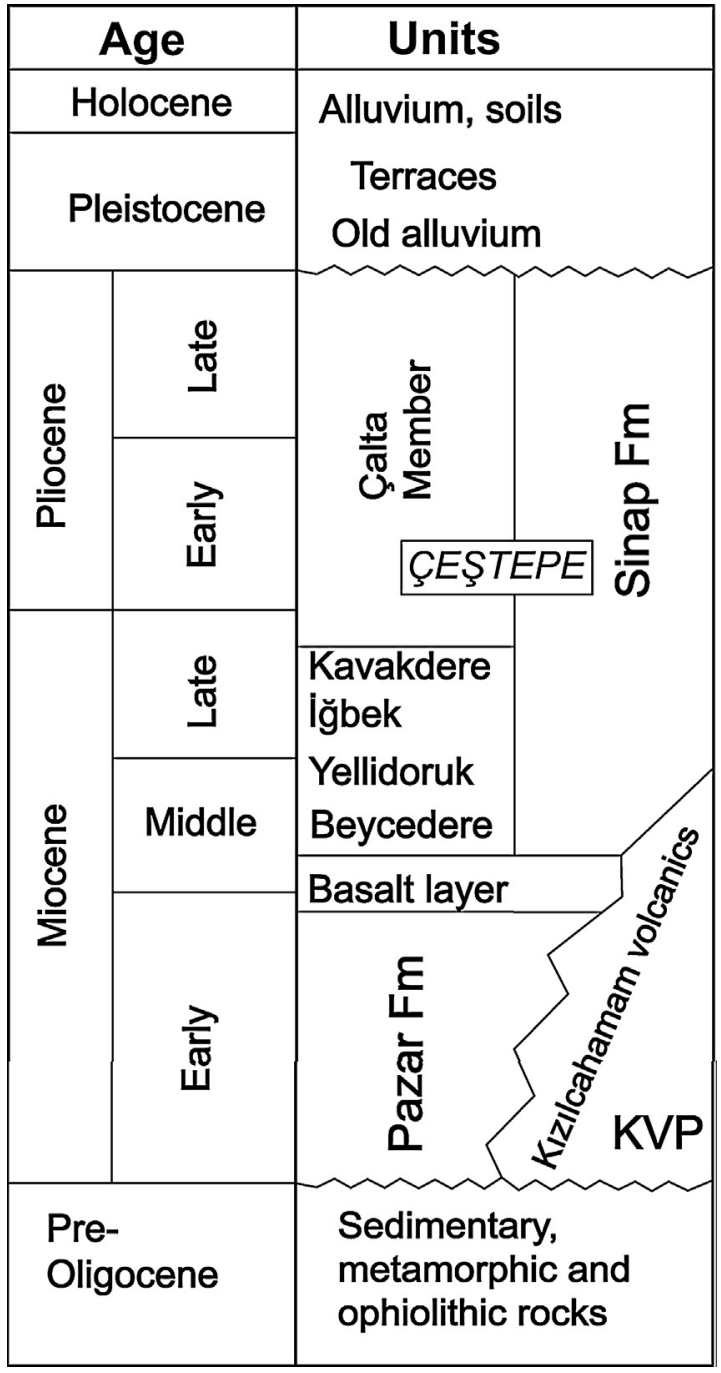

Fig. 2. Stratigraphy of Neogene units in the Ceștepe-Pazar area (modified from Lunkka et al., 2003), and position of the Çeştepe vertebrate locality.

Stratigraphie des unités néogènes dans la région de Çeştepe-Pazar (modifiée de Lunkka et al., 2003), et position de la localité à vertébrés de Çeștepe.

basin, depending on the present day observations, are marked on Fig. 1B. For more accurate boundaries, detailed studies are needed.

The term "Kazan Basin" was previously used by Toori (2005) without, however, a clear definition of its characteristics (origin, architecture, boundaries). It is out of the purpose of the present study to involve further in the definition of the Kazan Basin and its detailed geological features. Its stratigraphy and the position of the Çeştepe fossil locality are resumed here below.

\subsection{Stratigraphy of the Çeştepe-Kazan area}

The geology of the Kazan-Çeştepe region is shown on Fig. 3. Several geologists mapped the geology of the region north of Ankara, and they provided various ages for stratigraphic units and consequently different tectonic interpretations. Although in almost all geological maps the outcrop limits are similar, the stratigraphy and unit names are different from one study to another (e.g. Ruprecht, 1956; Tatlı, 1975; Erişen and Ünlü, 1976; Öngür, 1976; Erol et al., 1980; Türkecan et al., 1991; Duru and Aksay, 2002; MTA, 2002; Karaca, 2004; Rojay, 2013). On the other hand, the studies not dealing with mapping used stratigraphic unit names given by the previous ones, but reorganized the stratigraphy according to their own age data (e.g. Lunkka et al., 2003; Toori, 2005; Kahraman, 2014). Consequently, the geological evolution of the Ankara region during the Neogene appears particularly complicated and confusing. It is beyond the scope of this study to discuss the stratigraphies given in previous publications. We aim here to introduce the local stratigraphy with the unit names used by Lunkka et al. (2003) for sedimentary rocks and by Türkecan et al. (1991) and Duru and Aksay (2002) for volcanic rocks (Figs. 2 and 3).

In the study area, Miocene-Pliocene and younger rocks unconformably overlay the older (pre-Neogene) units (Fig. 2). The youngest unit of the pre-Neogene rocks is the marine middle Eocene Güvenç Formation, which is formed of Nummulites and Assilina rich limestones, marls and argillaceous limestones (Fig. 3). This unit represents the latest progress of marine transgression in Central Anatolia (Çayraz Fm in the Haymana Basin, Orhaniye Fm north of Ankara; Gökten et al., 1988; Toori, 2005).

Neogene units formed after the Alpine orogeny, which cover large areas in Central Anatolia, are generally much less deformed than the older units, and they show often lateral and vertical lithological changes. Lacustrine deposits are common during the early and middle Miocene, while fluvial and alluvial systems dominate during the late Miocene and Pliocene. In the basins that surround the Kizılcahamam volcanic province (KVP), sedimentary infill shows great discrepancies; for instance while in the ÇankırıÇorum and Beypazarı basins, late Miocene and early Pliocene evaporite lakes occupied large areas, (Fig. 1B, C), evaporite deposits are not known in the Neogene sedimentary succession of the Kazan Basin. The Neogene units of the Kazan Basin are summarized here below from the bottom to the top.

Pazar Formation: This unit is commonly observed in the study area. It was defined by Tatl (1975) around Pazar town, which is built on younger deposits (!), about $5 \mathrm{~km}$ to the north east of Çeştepe (Fig. 3). The Pazar Formation laterally interfingers with the Kizilcahamam volcanics (Figs. 2 and 3). The main lithologies are clayey limestone, marl and claystone, locally cherty limestone, sandstone and tuff, with occasional thin coal seams. The dominant color of the unit is white and light gray.

Locally, depending on the abundance and alteration of tuff input, white, green or yellow levels can be observed. Its thickness was measured near Kazan to be about 250 m (Karaca, 2004). This formation may be observed as well in lowlands and altitude terrain, because it is greatly faulted and folded by tectonic activity. According to its main lithologies, the Pazar Formation was formed in lake and swamp environments with water depth varying in times (Tatli, 1975). The lateral equivalents of the unit were named in previous studies as Akhüyük Fm (Erol et al., 1980), Hançılı Fm (Duru and Aksay, 2002), Çeltikçi Fm (Rojay, 2013). These authors suggested to date it, based on relative stratigraphy or pollen record, as Miocene, middle-late Miocene or late Miocene. These formation names and ages cannot be applied at least for the Kazan area. Because of the occurrence of hominoid primates, the sedimentary deposits of the Kazan area have been intensively investigated for stratigraphy, sedimentology and vertebrate paleontology. They have been precisely dated by fossils, magnetostratigraphy and radiometric dating (Sen, 1991; Alpagut et al., 1996; Fortelius et al., 2003). The basaltic flow, which separates the Pazar Formation from the overlaying Sinap Formation is dated to 15.8 my by the K-Ar method (Kappelman et al., 2003). This basalt flow is different from the Özlü basalt given on Fig. 3. Also the mammal localities 24 and $24 \mathrm{~A}$ at the Inönü district near Sarllar village, which are correlated to the mammalian zone MN6 (Fortelius et al., 2003) are in this formation. All this shows that the Pazar Formation was settled during the early and early middle Miocene, at least in the Kazan area.

Kizılcahamam Volcanics: In the study area, Neogene volcanic rocks are observed laterally interfingering with the Pazar Formation. They represent a small part of the southern section of 


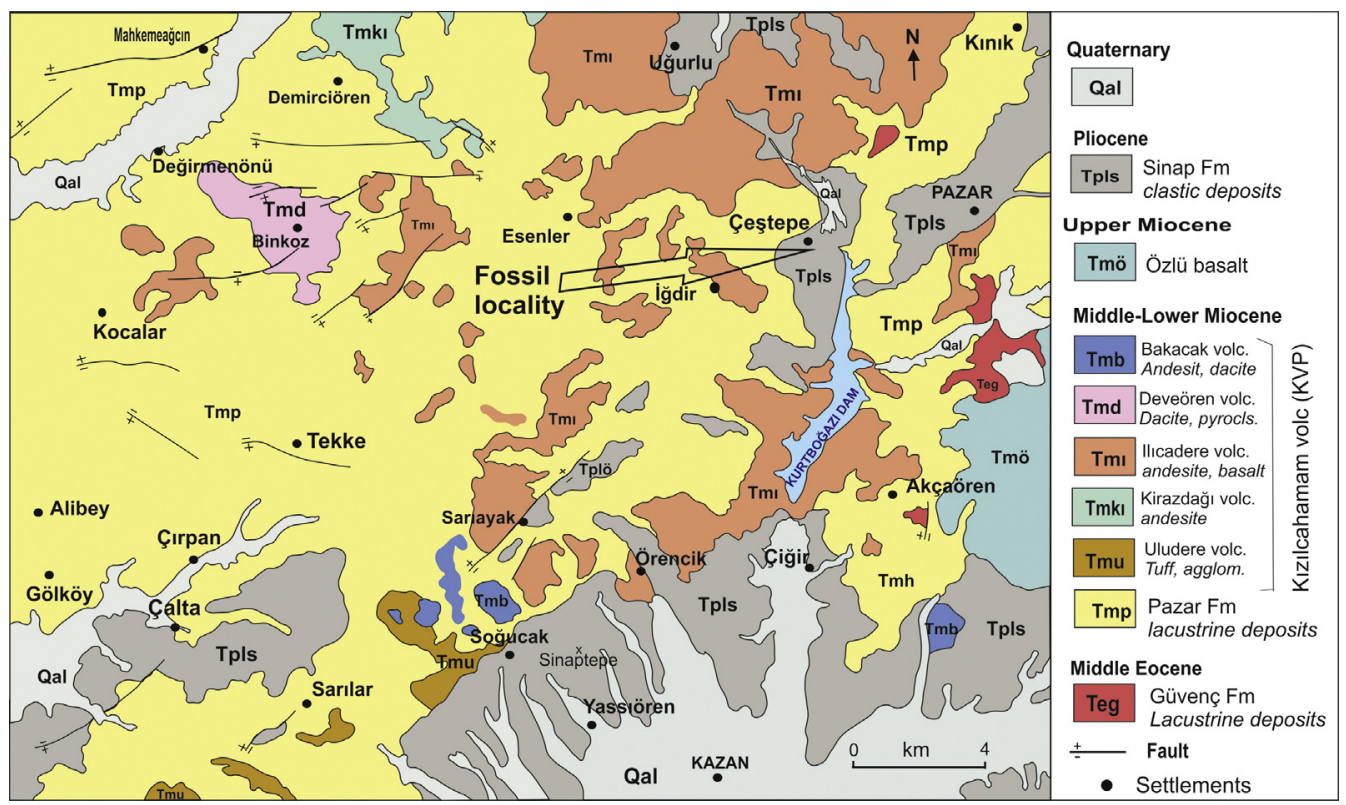

Fig. 3. Detailed geological map of the region situated between the towns of Pazar, Kazan and Çalta. See Fig. 1 for fossiliferous sites in the region. Carte géologique détaillée de la région située entre les bourgs de Pazar, Kazan et Çalta. Voir Fig. 1 pour les sites fossilifères de la région.

Modified after Duru and Aksay, 2002.

the Kizilcahamam Volcanic Province (KVP). The main part of this province is situated further north and spread across an area of $12.500 \mathrm{~km}^{2}$. It culminates at Köroğlu Tepe to an altitude of 2400 meters (Figs. 1b and 3). This volcanic province is also known in the literature as Köroğlu volcanics, Galatia Massif and Galatia Volcanics (Türkecan et al., 1991; Toprak et al., 1996). Its main rock types are andesitic, trachytic and basaltic lavas, rhyolitic tuffs and pyroclastics. There are many volcanic eruptive centers, most of them around Kizilcahamam town, and the prominent center being Köroğlu Tepe. According to radiometric data, these are the product of three phased explosive volcanic events between 23-11 my (Türkecan et al., 1991; Wilson et al., 1997; Tankut et al., 1998). During the calm periods, lakes occupied large areas, and terrestrial sedimentary deposits, which also locally include coal formations, developed. These deposits also include several fossiliferous localities, the best known of which are Güvem-Keseköy with leave and vertebrate fossils and Bayındır Pelitçik silicified wood forest (localities 4 and 5 on Fig. 1B) (Kasaplıgil, 1978; Rückert-Ülkümen et al., 2002; Atabey and Saraç, 2004; Lopez-Antoñanzas et al., 2004; Hatipoğlu and Türk, 2009; Kazanc1, 2012). The majority of volcanic rocks in the study area are basaltic lava and coarse pyroclastics of the Ilıcadere volcanics (Türkecan et al., 1991) that are mostly derived from volcanic centers near Kızılcahamam (Fig. 3).

Sinap Formation: It covers the lowlands of the study area in the form of three patches around Kazan, Çalta and Çeştepe-Pazar (Pls on Fig. 3, Pl on Fig. 1). A typical erosional surface is developed on its outcrops. This formation is easily distinguished from the underlying Pazar Formation by its poorly consolidated sediments with yellowish, reddish, mottled gray, brown colors. It is almost totally composed of lithologies of alluvial and fluvial sediments dominated by loose conglomerates, sandstones and mudstones. Locally it includes lacustrine sediments that form thin bands. This formation is not much affected by the tectonics, and thus the bedding is almost horizontal (Rojay and Karaca, 2008). It covers Pazar Formation and older units with angular unconformity (Fig. 2). Although its usual thickness is between $40-100 \mathrm{~m}$, Karaca (2004) measured a section of $150 \mathrm{~m}$ northwest to Kazan.

This unit was defined by Tatlı (1975) along the slopes of Sinap Tepe at some $4 \mathrm{~km}$ northwest to Kazan, with a given age range as early Pliocene. In several basins of Central Anatolia, similar deposits are mapped, as shown in the MTA maps, as "undifferenciated clastics" or Örencik Formation (Duru and Aksay, 2002; MTA, 2002). In individual studies, it is named as Gölbaşı Fm south of Ankara, Etimesgut Fm (Erol, 1980), Memlik Fm (Gökten et al., 1988) and Yuva Group (Koçyiğit et al., 1988) north of Ankara. Karaca (2004) and Rojay and Karaca (2008) have used the name of Sinap Formation, but gave the age of the unit as Plio-Quaternary without taking into consideration paleontological and magnetostratigraphic ages already available in the literature. In all these studies, the age of this unit is given in relative terms based on the relative position similar lithologies in other basins. Fortelius et al. (2003) and Lunkka et al. (2003) carried out in 1990s detailed sedimentological, stratigraphic and in particular paleontological investigations in the Kazan Basin (Fig. 3), mainly concentrated around the type section of the Sinap Formation. Lunkka et al. (2003) distinguished five successive members (from the bottom to the top Beycedere, Yellidoruk, İğbek, Kavakdere and Çalta members), covering an interval of time from the middle Miocene to the early Pliocene (Fig. 2). The mammalian faunas from the first four members have been subject of detailed studies published in a volume edited by Fortelius et al. (2003), while the fauna from Çalta was published in a volume edited by Sen (1998a, 1998b). The outcrops seen around Ceștepe, Pazar and Kurtbogazi localities all belong to the Çalta Member. Its thickness near Çeştepe is about $45 \mathrm{~m}$, and it is composed of flood plain deposits (mudstones) cut off by stream channel sediments (loose conglomerates, sandstones). Around the Çeştepe village, where the vertebrate fossils are recorded, fossiliferous sediments correlates to the middle-upper horizons of the Calta Member. Mudstones and gravelly channel deposits are dominant (Fig. 4A-D). Sediments are not well consolidated, and consequently deeply cut by seasonal streams allowing the development of a recent fluvial network on the Çalta Member.

\section{Material and methods}

The vertebrate remains from Çeştepe have been found during the digging operations for the foundation of a private house at the village of Çeştepe. Adem Büyükköprü, a geologist who works at the 


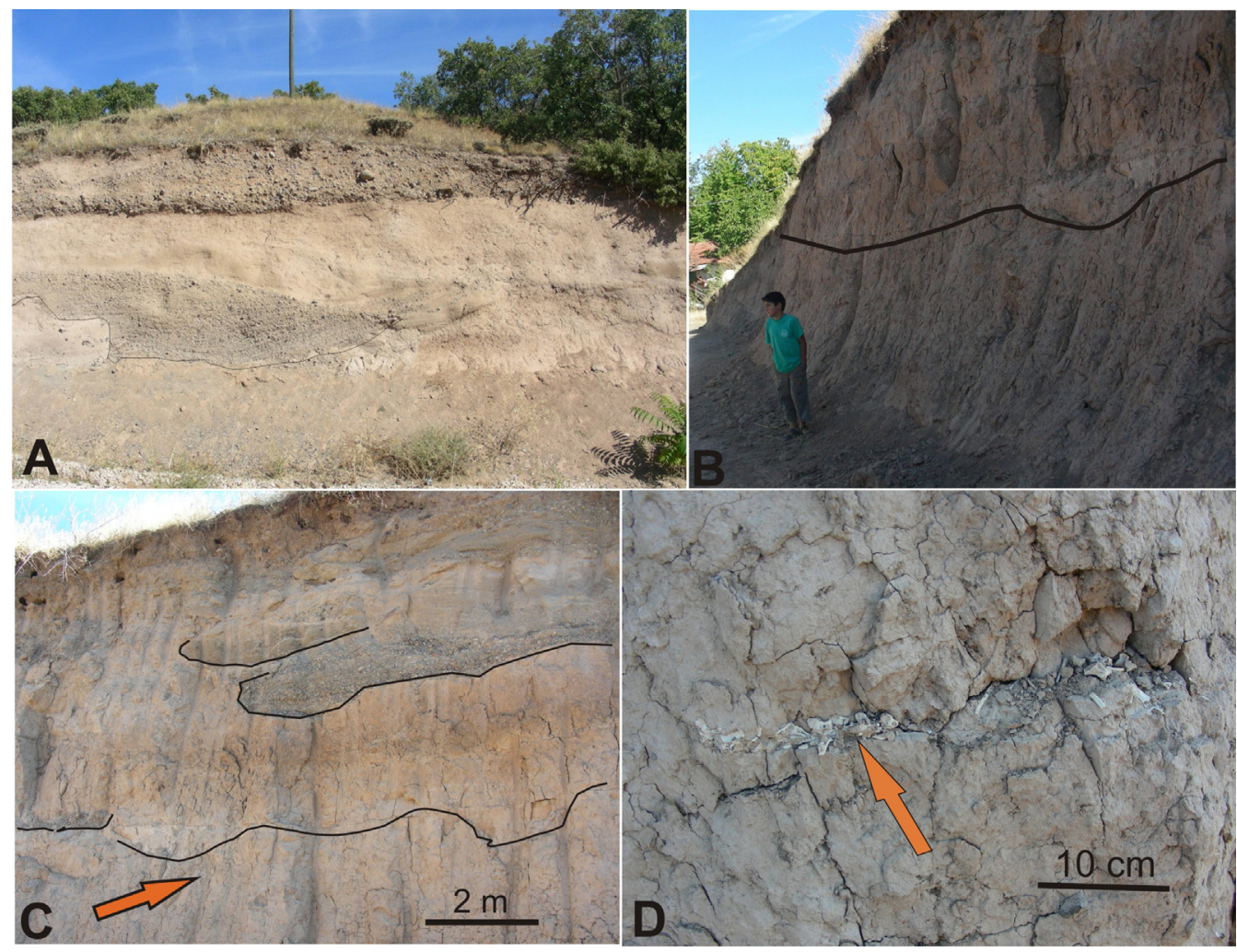

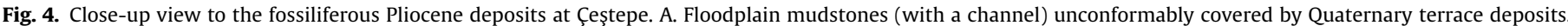

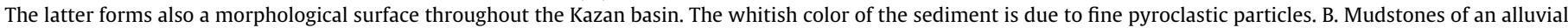

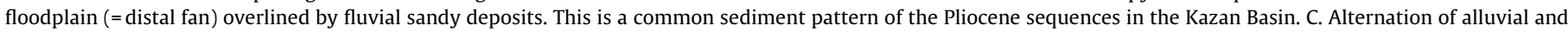

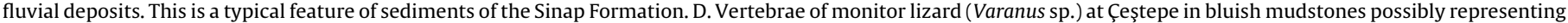
a shallow pond or marsh in a fluvial setting.

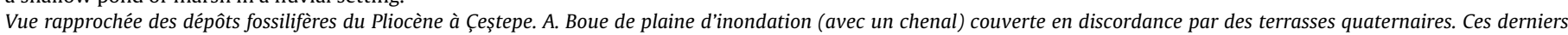

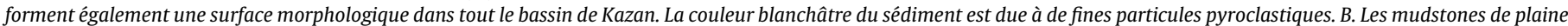

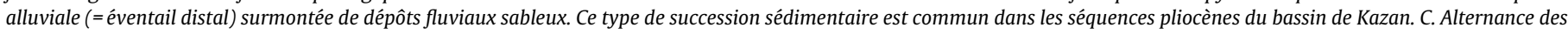

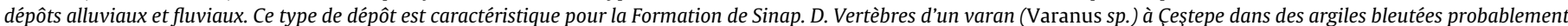
déposées dans un étang peu profond ou un marais dans un milieu fluvial.

Department of Water Supply and Sewerage of the city of Ankara, noted the presence of bones on the section (Fig. 4D). He stopped digging and warned on this discovery one of us (N. Kazanci) at the University of Ankara. A team from this university went the next day to Çeştepe and collected all visible bones and some matrix at the place of discovery. The matrix was sieved on a mesh of $1 \mathrm{~mm}$ to recover fragments not easily visible. The geographic coordinates of the finding place are N $40^{\circ} 19^{\prime} 30.89^{\prime \prime}$ and E $32^{\circ} 41^{\prime}$ $21.85^{\prime \prime}$.

Gelogists who collected this material at Çeştepe are not familiar with the techniques of digging and collecting fossil vertebrates. They have collected the fossils without consolidation. Fresh fractures on bones, the presence of numerous small fragments belonging to an ochotonid skull, fragmentary state of lizard vertebrae that apparently belonged to the same individual show that the material was initially consisted of more complete specimens, but damaged during excavation and salvage operations.

The material from Ceștepe includes the remains of an ochotonid lagomorph and several lizards. Lizards are represented by $88 \mathrm{spec}-$ imens referred to three taxa: cf. Lacerta sp., non-Anguis Anguinae indet. and Varanus sp. The numerous fragmented vertebrae probably belonged to at least partially complete skeleton of monitor lizard as seen on Fig. 4D. The ochotonid is represented by three fragmentary lower jaws, skull fragments and one upper cheek tooth. We tried to fix bone fragments to complete some specimens as much as possible, without great success due to the loss of contact between the fragments. All this material is housed at Ankara University, department of Engineering Geology.
For the description of ochotonid teeth, we used the terminology of López-Martínez (1989). Upper cheek teeth are abbreviated with capital letters and lower cheek teeth with lower case letters. All measurements are in millimeter.

\section{Systematic study}

Class Reptilia Laurenti, 1768

Order Squamata Oppel, 1811

Superfamily Lacertoidea Oppel, 1811

Family Lacertidae Oppel, 1811

Genus Lacerta Linnaeus, 1758

\section{cf. Lacerta sp.}

Material: one fragmentary right dentary (CT-10).

Description: The incomplete right dentary CT-10 (Fig. 5A, B) preserves the anterior portion, $8 \mathrm{~mm}$ long, up to the eighteenth tooth position. Teeth are (at least partially) preserved in the positions from two to seven, nine, 11, 13, 15 and 16; they are pleurodont, long and cylindrical. The anterior teeth are anterodorsally directed and show a single cusp. The other teeth are dorsally directed and the well-preserved crown in the ninth position is clearly bicuspid, with a very small anterior cusplet separated by a shallow lingual groove from the main cusp. Other teeth, as the one preserved in the eleventh position, show a lingual groove probably indicating the former presence of an anterior cusplet. The dental crest is dorsally curved and its medial edge is rounded. The Meckel's groove is fully open, reaching the anterior tip of the dentary, and 


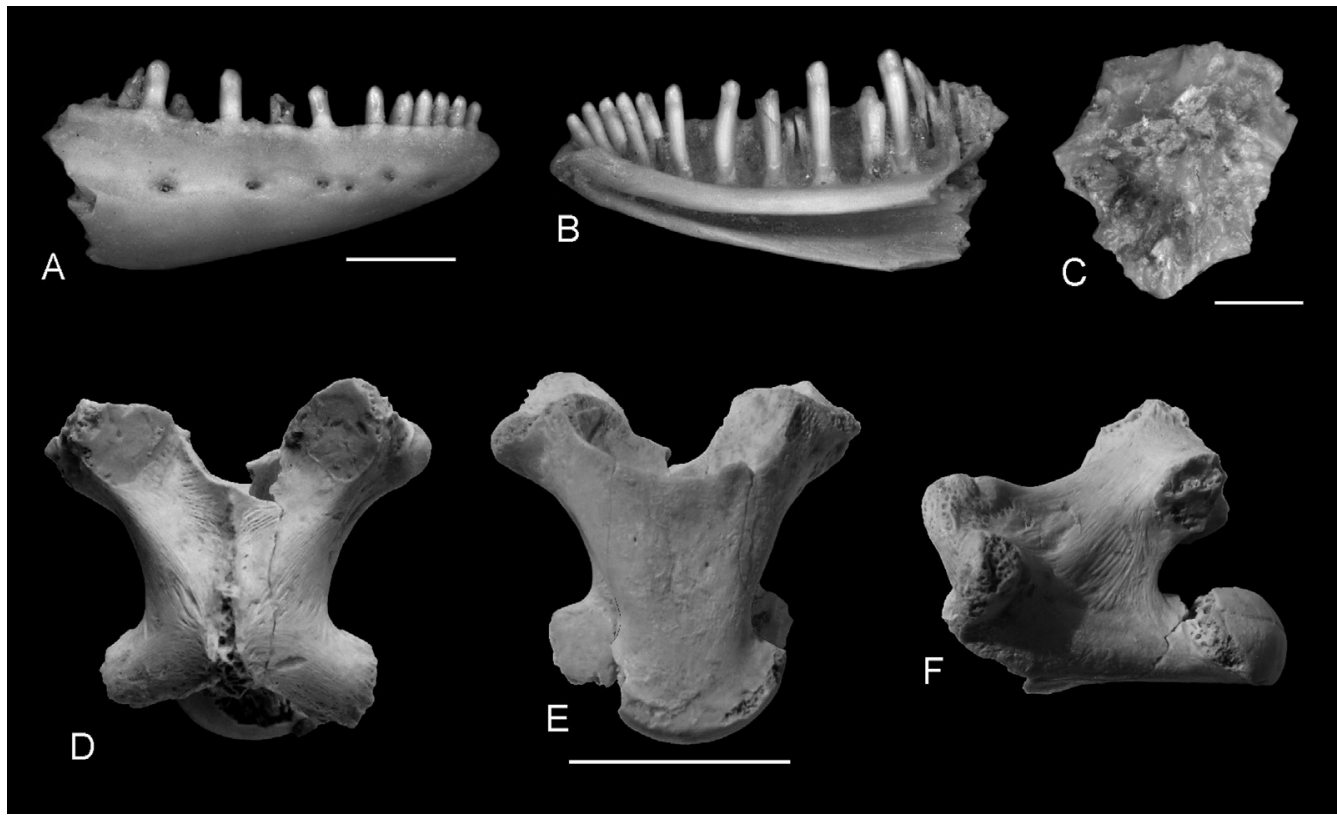

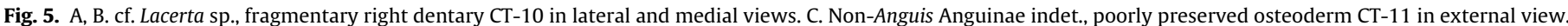
D-F. Varanus sp., trunk vertebra CT-12 in dorsal, ventral, and left lateral views. Scale bars equal $2 \mathrm{~mm}$ in A-C and $10 \mathrm{~mm}$ in D-F.

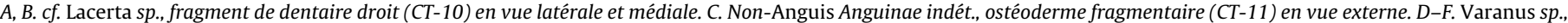
vertèbre du tronc $(C T-12)$ en vue dorsale, ventrale et latérale gauche. Les échelles correspondent à $2 \mathrm{~mm}$ pour $A-C$ et à $10 \mathrm{~mm}$ pour $D-F$.

widens posteriorly. In lateral view, the dentary deepens backward and hosts six mental foramina aligned to the dorsal edge of the element.

Remarks: The characters described above, the pleurodont bicuspid dentition and the open Meckel's canal in particular, fit well with those of lacertid lizards (among others Arnold, 1973, 1989; Barbadillo and Sanz, 1983; Barahona and Barbadillo, 1997; Arnold et al., 2007). The size of the only available element suggests the presence of a member of Lacerta that according to Uetz et al. (2016) is currently represented in Anatolia by the following species: Lacerta agilis Linnaeus, 1758, Lacerta media Lantz and Cyrén, 1920, Lacerta pamphylica Schmidtler, 1975, Lacerta strigata Eichwald, 1831, Lacerta trilineata Bedriaga, 1886, and Lacerta viridis (Laurenti, 1768). However, since the comparative osteology of these species is currently unknown and, moreover, it cannot be excluded that the single fragmentary lacertid element currently available (CT-10) belongs to a subadult representative of the larger genus Timon or even to an extinct taxon, the identification is limited at genus level, with the addition of the qualifier cf. indicating close morphological similarity to Lacerta.

Lacertid lizards were reported from about 10 Turkish localities whose age ranges from the late Oligocene to the Middle Pleistocene (Böhme and Ilg, 2003). Some of them have been even referred to the genus Lacerta, but only those from the middle Pleistocene of Emirkaya (Venczel and Sen, 1994) have been described and figured. No other lacertid genera than Lacerta were reported for Turkey despite the fact that it currently hosts 13 genera (Uetz et al., 2016). In the same broad geographic area, a green lizard, Lacerta gr. L. viridis, has been recently reported from the Early Pleistocene of Dmanisi in Georgia (Blain et al., 2014) and Lacerta sp., Ophisops elegans and Lacertidae indet. from the Middle Pleistocene of Azokh 1 Cave in Nagorno Karabakh region (Blain, 2016).

Superfamily Anguioidea Gray, 1825

Family Anguidae Gray, 1825

Subfamily Anguinae Gray, 1825

non-Anguis Anguinae indet.
Material: 1 osteoderm (CT-11).

Description: The preserved portion of the osteoderm CT-11 (Fig. 5C) is $5.0 \mathrm{~mm}$ wide and $5.1 \mathrm{~mm}$ long. The lateral and posterior edges are incomplete. The external surface is altered, but the following characters can be detected: presence of an anterior smooth strip posteriorly followed by a much larger and vermiculated area divided in two by a longitudinal ridge. The internal surface does not preserve any relevant character (i.e. the presence of foramina cannot be ascertained).

Remarks: Isolated osteoderms are very common in the fossil record (for example, more than 8000 in the late Miocene of Moncucco Torinese - Italy; Colombero et al., 2017) probably because they are massive bony structures that are very numerous in a single lizard individual and they are also easy to detect because of their characteristic shape and relatively large size. However, even if the skull and lower jaw osteology of the western Palaearctic anguines was carefully described (among others: Roček, 1980; Klembara et al., 2010, 2014; Klembara, 2012), little attention has been paid to the comparative morphology of the osteoderms and therefore only Anguis can be easily and reliably detected. As already remarked by Colombero et al. (2014), the osteoderms coming from a certain site are usually referred to the taxon identified on the basis of cranial characters, and when two taxa are recognized in a single site on the basis of cranial elements it has been suggested not to refer the osteoderms to them (Augé and Rage, 2000).

Anguid lizards were reported in about 15 Turkish localities (Böhme and Ilg, 2003), but with the exception of the materials referred to Pseudopus from the early Pliocene of Çalta (Rage and Sen, 1976; Sen and Rage, 1979) and the middle Pleistocene of Emirkaya (Venczel and Sen, 1994), all the others were identified at family level. Pseudopus apodus is the only non-Anguis anguine currently inhabiting Anatolia (Uetz et al., 2016) and was recently reported from the Middle Pleistocene of Azokh 1 Cave (Nagorno Karabakh region; Blain, 2016).

Superfamily Varanoidea Camp, 1923

Family Varanidae Gray, 1827 
Genus Varanus Merrem, 1820

Varanus sp.

Material: two trunk vertebrae (CT-12 and 13); 20 fragments referable to at least 15 trunk vertebrae (CT-14); 1 fragmentary sacral vertebra (CT-15); 15 fragmentary caudal vertebrae (CT-16); 31 vertebral fragments (CT-17); 1 fragmentary right scapulocoracoid (CT-18); 1 fragmentary right ischium (CT-19); 1 distal epiphysis of a (?)tibia (CT-20); 1 right astragalocalcaneum (CT-21); 1 tarsal (CT-22); 5 metapodials (CT-23); 7 phalanges (CT-24).

Description: Despite not being complete, because the anterior edge of the neural arch, the tip of the neural spine, the dorsal portion of the cotyle and the condyle are partially damaged, the trunk vertebra CT-12 (Fig. 5D-F) is the most informative element of this taxon. The preserved portion of the anterior area of the neural arch is concave. The prezygapophyses are markedly tilted in dorsolateral direction. The synapophyses are rather globular and noticeably protruding laterally, but with a narrow connection with the lateral edge of the cotyle. The neural canal is proportionally narrow and roundish. The cotyle and the condyle are markedly compressed dorsoventrally, with a ventral edge very much more posteriorly placed than the dorsal edge. The lateral sides of the vertebra and part of those of the neural arch are distinctly striated. The centrum, $11.7 \mathrm{~mm}$ long, shows lateral edges distinctly converging posteriorly and with a significant precondylar constriction.

Caudal vertebrae are characterized by the following characters: cotyle and condyle similar to those described for the trunk vertebrae; centrum anteroposteriorly elongated; lateral apophyses dorsoventrally flattened and variably broadened; pedestals for chevron bones present and well-defined; precondylar constriction. The largest caudal vertebra with a measurable centrum (CT-16a) is $9.8 \mathrm{~mm}$ long.

The rest of the remains are very fragmentary and/or not taxonomically diagnostic (as the astragalocalcaneum CT-21) because of the absence of comparative studies on their morphology.

Remarks: The size and general morphology of the vertebrae, the dorsoventrally compressed cotyle and condyle with their ventral edge much posterior than the dorsal one, and the precondylar constriction in particular (an autoapomorphy of Varanus, see Smith et al., 2008, and literature therein), clearly support the identification of a monitor lizard of the genus Varanus. However, their morphology is not congruent with that of Varanus griseus (Daudin, 1803), the only species currently inhabiting Anatolia (with a single taxon/locality datum in southeastern Turkey; Sindaco and Jeremcenko, 2008). The distinctly converging lateral edges of the centrum (in ventral view) and therefore the marked precondylar constriction of the vertebra CT-12 are in contrast with the morphology of $V$. griseus, but reminiscent of a generalized morphology of many other species with at least a relatively large size (see fig. 3 in Delfino et al., 2013). Such morphology was reported in the Mediterranean area for both the late Miocene extinct Varanus marathonensis Weithofer, 1888 and Varanus amnhophilis Conrad et al., 2012.

Varanus was reported in four Turkish localities (Böhme and Ilg, 2003) ranging in age from the middle Miocene to the early Pliocene, and isolated trunk vertebrae from the early Pliocene of Çalta (Rage and Sen, 1976) with a morphology similar to those from Çeştepe were actually referred to V. marathonensis. However, besides doubts on the validity of the latter species, the vertebral morphology is not diagnostic at species level and therefore the material here described is simply referred at genus level. Since all fossil remains from Çeştepe could belong to a single individual (because of the congruent size and absence of duplications) all the rest of the material is referred to the same taxon.

Mammalia Linnaeus, 1758
Table 1

Measurements of lower and upper cheek teeth of Ochotona mediterranensis from Çeştepe, Turkey.

Dimensions des dents jugales d'Ochotona mediterranensis de Çeştepe, Turquie.

\begin{tabular}{|c|c|c|c|c|c|c|c|}
\hline \multirow[t]{2}{*}{ Tooth } & \multirow[t]{2}{*}{$n$} & \multicolumn{2}{|l|}{ Length } & \multicolumn{2}{|c|}{ Width trigonid } & \multicolumn{2}{|c|}{ Width talonid } \\
\hline & & Range & $\mathrm{X}$ & Range & $\mathrm{X}$ & Range & $\mathrm{X}$ \\
\hline p3 & 1 & & 1.36 & & 1.25 & & \\
\hline $\mathrm{p} 4$ & 2 & $1.38-1.47$ & 1.43 & $1.33-1.43$ & 1.38 & $1.48-1.54$ & 1.51 \\
\hline $\mathrm{m} 1$ & 3 & $1.48-1.51$ & 1.50 & $1.49-1.57$ & 1.52 & $1.56-1.61$ & 1.58 \\
\hline $\mathrm{m} 2$ & 3 & $1.30-1.53$ & 1.45 & $1.42-1.57$ & 1.51 & $1.49-1.55$ & 1.52 \\
\hline P4 & 1 & & 1.08 & & 1.64 & & 1.97 \\
\hline
\end{tabular}

$n$ : number of specimens; $\mathrm{X}$ : mean values.

Order Lagomorpha Brandt, 1885

Family Ochotonidae Thomas, 1897

Genus Ochotona Link, 1795

\section{Ochotona mediterranensis Suata Alpaslan, 2009}

Material: Isolated right $\mathrm{P} 4(\mathrm{CT}-1)$; right mandible fragment with p3-m2 (CT-2); right mandible fragment with detached incisor, alveolus of $\mathrm{p} 3$ and $\mathrm{p} 4-\mathrm{m} 2$ (CT-3); right mandible fragment with $\mathrm{m} 1-\mathrm{m} 2$ (CT-4), fragment of ramus of a right mandible (CT-5). The material also includes several small fragments that apparently belonged to a skull. We tried to fix them to rebuild this skull, without success. The anatomical position of most fragments is not recognizable. Only one pair of occipital condyles together and parts of occipital bones are reliably referable to this ochotonid. The material is homogenous and does not contain fossils that may belong to any other taxon.

Measurements: See Table 1.

Description: Putting together the available fragments, it is possible to restore the mandible (Figs. 6 and 7). The missing parts are the posterior part of the body, part of the angular process and $\mathrm{m} 3$. In lateral view, the body is deepest below p4 $(5.20 \mathrm{~mm})$, while the ventral margin of the bone shows a clear swelling forward and backward. The tip of the incisor reaches the occlusal level of cheek teeth. The length of the diastema is $4.58 \mathrm{~mm}$ on the most complete specimen (CT-2), and it is gently concave. The p3-m3 length can be estimated as about $7 \mathrm{~mm}$. Below the $\mathrm{p} 4$, there is a strong taurus mandibulae, which is a round bone thickening for the attachment of masseter muscles. The lateral surface of the body has numerous tiny foramina, mainly grouped below $\mathrm{p} 3$ and $\mathrm{m} 1$. The anterior mental foramen is situated below the p3 (CT-3) or p3-p4 limit (CT-2). The posterior mental foramen is situated about $3.5 \mathrm{~mm}$ below the $\mathrm{m} 2$.

On the fragment of ramus, the articular process has an articular surface that covers the head of this process. Dorsally it is teardrop shaped. The coronoid process is not preserved. The angular process is partly preserved and it is apparently quite strong.

In medial view, the articular surface of the symphysis extends on $2.35 \mathrm{~mm}$ below the diastema. The medial face of the body is concave between the alveolar margin and the protuberance of the lower incisor. Several small foramina are scattered on this face.

In ventral view, the mylohyoid line starts where the lower incisors ends and it extends backward along the medial side till below $\mathrm{m} 2$.

A complete lower incisor measures $12.3 \mathrm{~mm}$ in length. It is gently curved. The enamel only covers the mesial face (width $1.51 \mathrm{~mm}$ ). The section is almost triangular. The anterior edge bears two wear facets, the one dorsal on $2.71 \mathrm{~mm}$ and the other medial on $2.50 \mathrm{~mm}$, both separated by a right angle. Inside the mandible, the distal end of the incisor reaches the level of p4-m1 boundary, and it is lingually rooted next to the premolars.

From the cheek teeth, the p3 is slightly longer than wide. The anteroconid has a badly defined trefoil occlusal outline with anterolateral and anteromedial depressions without cement. Its length and width are similar $(0.56 \mathrm{~mm})$. The anteroconid is con- 
nected to the posterior part by a narrow isthmus. The paraflexid is clearly shorter than the protoflexid, and both are oblique backward. The hypoflexid is shallow, V-shaped and rather transverse. All three flexids are filled with cement. The mesoflexid is lacking. The enamel is thick around the protoconid, in front of the paraconid, and along the posterior margin of the hypoconid. Enamel is moderately thick and rather homogeneous on the anteroconid.

The $\mathrm{p} 4, \mathrm{~m} 1$ and $\mathrm{m} 2$ are bilophodont as usual in all ochotonids. The anterior loph is diamond shaped, while the posterior loph is rather crescent shaped. The posterior loph is a little larger than the anterior loph in $\mathrm{p} 4$ and $\mathrm{m} 1$, but slightly narrower or equivalent in $\mathrm{m} 2$. The enamel is thick on the posterior margin of both lophs, which corresponds to the main shearing blades, and rather thin on the anterior margins; in any case, it is never interrupted.

A complete isolated upper cheek tooth is determined as right P4 because of its anterior loph clearly shorter and narrower than the posterior loph (1.64 versus $1.97 \mathrm{~mm}$ ). The hypoflexus ends quite far

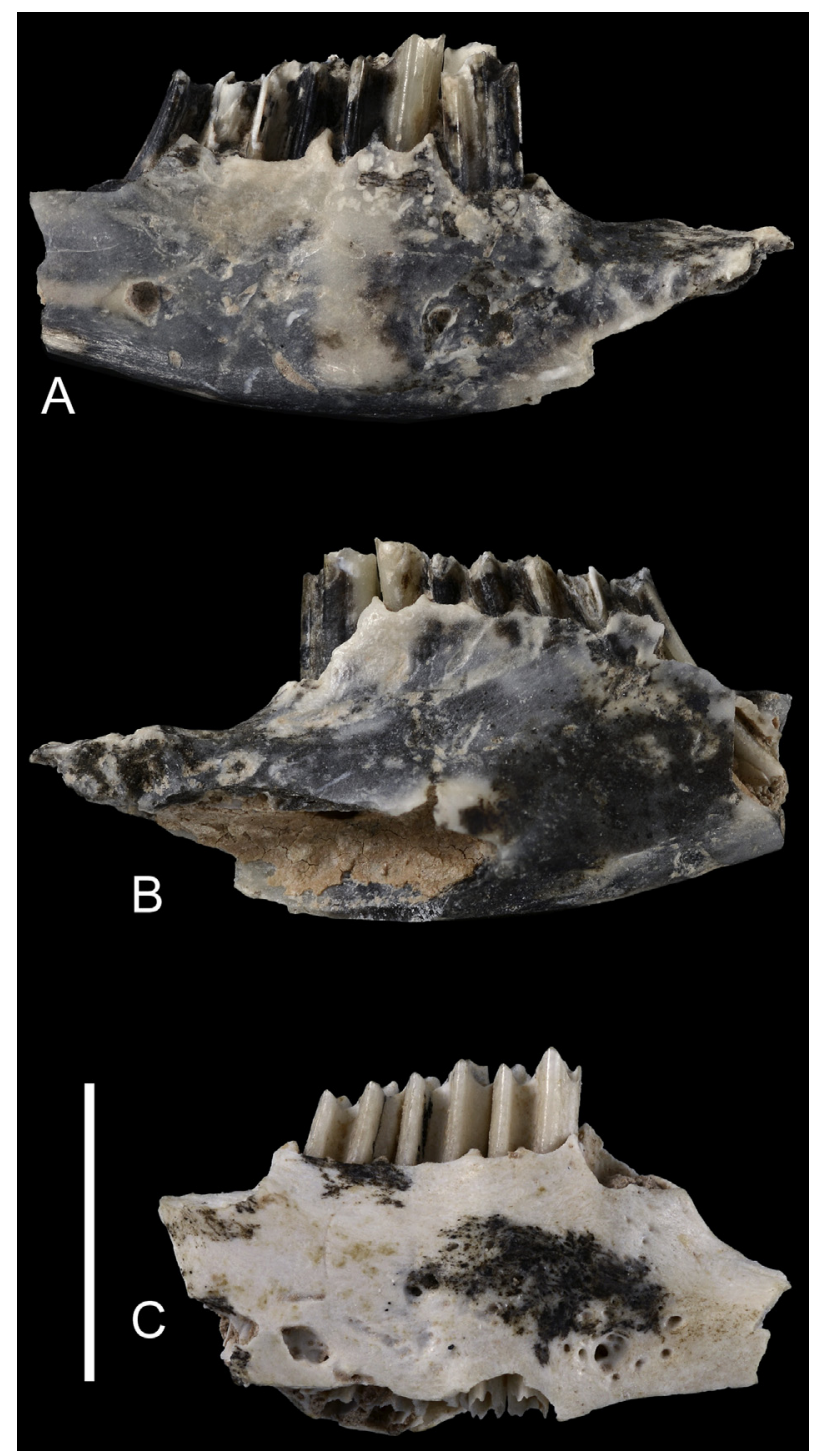

Fig. 6. Ochotona mediterranensis from Çeştepe, early Pliocene of Kazan Basin. A. Right mandible (CT-2) with p3-m2 in labial view. B. Same specimen in lingual view. C. Right mandible fragment (CT-3) with the alveolus of $\mathrm{p} 3$ and $\mathrm{p} 4-\mathrm{m} 2$ in labial view. Scale bar equals $5 \mathrm{~mm}$.

Ochotona mediterranensis de Çeștepe, Pliocène inférieur du bassin de Kazan. A. Mandibule droite (CT-2) avec p3-m2 en vue labiale. B. Même spécimen en vue linguale. C. Fragment de mandibule droite (CT-3) avec l'alvéole de p3 et p4-m2 en vue labiale. L'échelle correspond à $5 \mathrm{~mm}$. from the labial margin. The enamel is thick on the mesial margin of lophs but thin on their distal margin; it lacks on the labial margin. The shaft is moderately curved labially and wrinkled mesially.

Remarks: The Çeştepe ochotonid clearly belongs to the genus Ochotona in having small-sized cheek teeth, p3 with a simple occlusal pattern, two labial and one lingual flexids, the anteroconid of $\mathrm{p} 3$ without flexid and connected to the posterior complex by a narrow isthmus.

Among the most similar ochotonids, the genus Ochotonoides Teilhard de Chardin and Young, 1931 is different in being of very large size, and in having large anteroconid on p3 with folded and cemented flexids. The genus Ochotonoma Sen, 1998a, 1998b is also different in being larger in size, and, in particular, in having p3 with a large anteroconid and a short talonid; its anteroconid is penetrated by labial and/or lingual flexids filled with cement; the protoflexid and paraflexid are larger, deeper and strongly directed backward; the hypoflexid is narrow, and the lophs on p4-m2 are compressed mesio-distally. Pliolagomys Agadjanian and Erbajeva, 1983 is another ochotonid known from the Pliocene and early Pleistocene of Eastern Europe and Western Asia. The three species referred to this genus are larger in size than the Çeştepe specimens, their p3 have anteroconid enamel more or less folded, the isthmus between the anteroconid and posteroconid is labially shifted because the paraflexid is twice deeper than the protoflexid, and hypoflexid narrower.

The genus Ochotona has a large distribution in Asia and western North America with 28 extant species generally recognized based on morphological as well as molecular studies (Hoffmann and Smith, 2005; Ge et al., 2013; Lissovsky, 2014). Some of the extant species are also known as fossil during the Pleistocene, e.g., Ochotona pusilla (Pallas, 1769), which has a large distribution in Eurasia during the Pleistocene (Malatesta, 1951; Malez, 1969; Erbajeva et al., 2001). In addition to the extant species, Erbajeva et al. (2015) recognized 44 extinct species of Ochotona in Europe and in particular Asia. As we will discuss here below, the question of the synonymy of some species is an ongoing debate among the lagomorph specialists, which is out of the purpose here. Actually, such a question cannot be solved without a complete revision of available collections, and perhaps more abundant and better preserved specimens.

During the last decade some effort was invested for a better description of the European and some Asian fossil species (see in particular Erbajeva et al., 2001; Sen, 2003; Fostowicz-Frelik, 2008; Fostowicz-Frelik and Frelik, 2010; Čermák, 2010, 2016; Čermák and Rekovets, 2010; Delinschi, 2014) and for morphological cladistic analysis of most extinct and some extant species (Fostowicz-Frelik et al., 2010; Ge et al., 2013). These studies provide reliable criteria for comparing the Çeştepe ochotonid with others for its systematic assignment.

Ochotona sp. cf. O. lagreli Schlosser, 1924 from late middle Miocene locality of Damiao in Inner Mongolia (Zhang et al., 2012) is apparently the oldest record referred to the genus. Ochotona ozansoyi Sen, 2003 from the late Vallesian of Turkey (dated to 9.4 Ma) and Ochotona kalfense (Lungu, 1981) from the late Vallesian of Moldova (ca. 9-9.5 Ma) evidence that this genus, probably originated in East Asia, already reached the eastern Mediterraneansoutheastern Europe in late Miocene (Sen, 2003; Čermák, 2016). O. ozansoyi was recovered in Turkey in three localities (Sinap Loc. 84, Inönü 1 and Küçükçekmece) (Sen, 2003, 2016), and O. kalfense at Kalfa (Moldova), all correlated to the late Vallesian. Both species are larger in size compared to the Çeştepe specimens, have larger and simple-shaped anteroconid and shorter posterior segment on the $\mathrm{p} 3$, and their lower (upper) cheek teeth are curved labially (lingually), while in Plio-Pleistocene representatives of Ochotona, the lower cheek teeth become rather strait, and the curvature of upper cheek teeth decrease. We consider the genus Proochotona 


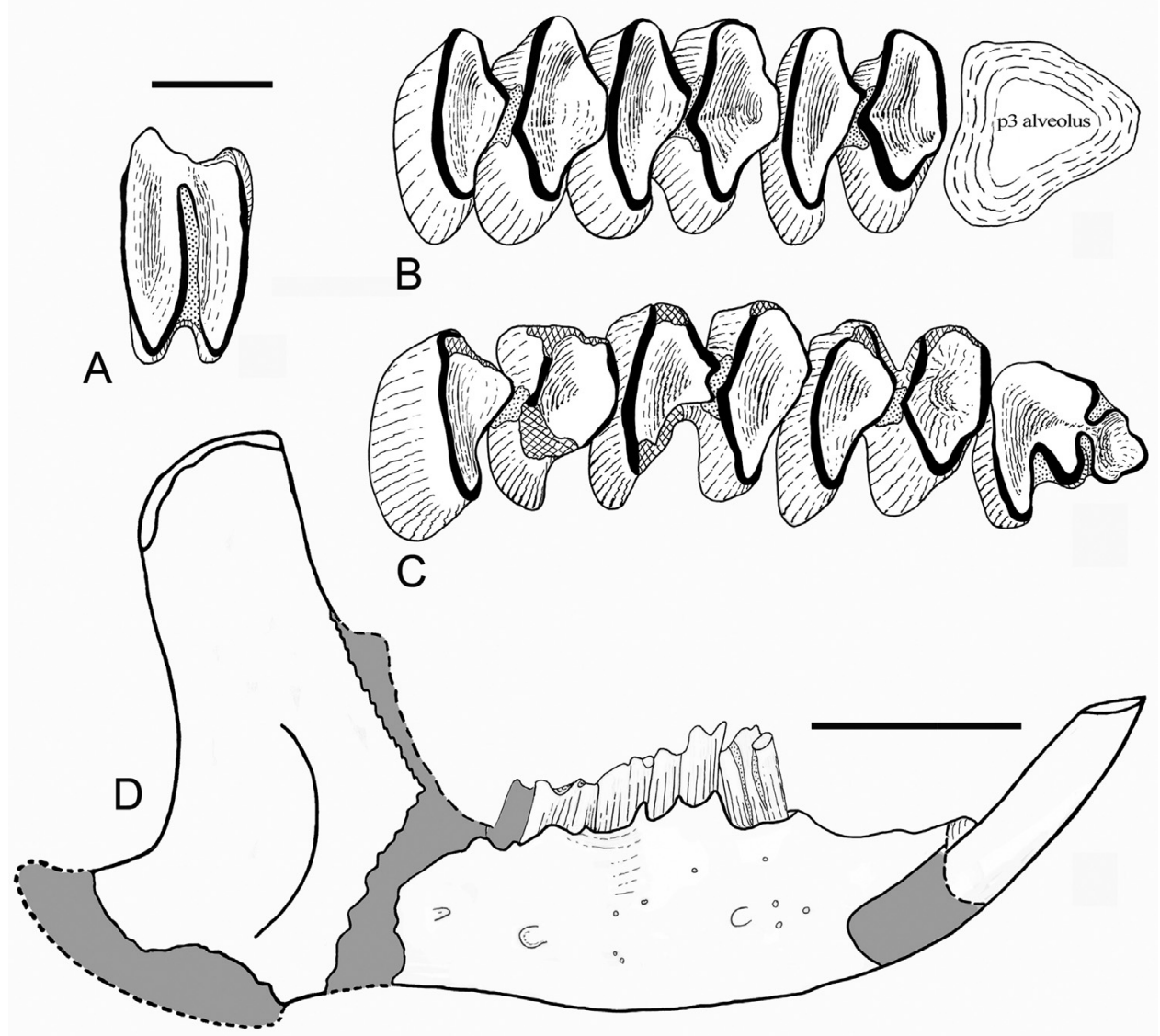

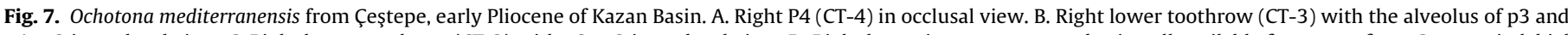

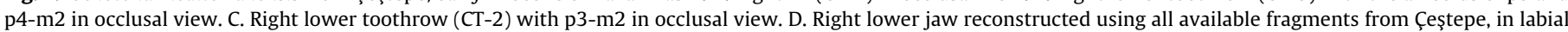

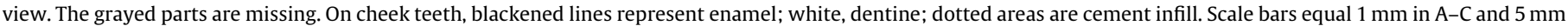
in D.

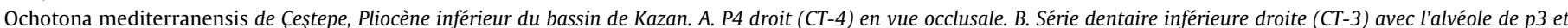

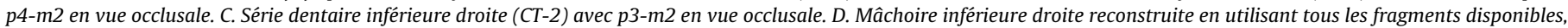

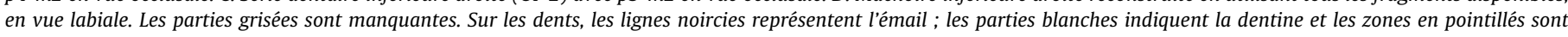
remplies de cément. Les échelles correspondent à $1 \mathrm{~mm}$ pour $A-C$ et à $5 \mathrm{~mm}$ pour $D$.

Khomenko, 1914 as a junior synonym of Ochotona (see discussion in Sen, 2003; Čermák, 2016). Other Ochotona species in Europe and Turkey are all from Plio-Pleistocene localities.

The size is used as an important criterion to distinguish extinct species of Ochotona. Erbajeva $(1988,1994)$ grouped Ochotona species as small, medium and large-sized species. Later on, Fostowicz-Frelik et al. (2010) used this criterion in their phylogenetic analysis. They defined as small the species having p3-m3 toothrow length lower than $8 \mathrm{~mm}$, medium-sized for length between $8.1-9.9 \mathrm{~mm}$, and large-sized the species having $\mathrm{p} 3-\mathrm{m} 3$ longer than $10 \mathrm{~mm}$. In this classification, the Çeştepe ochotonid ranks among the small-sized species (p3-m3 length estimated to about $7 \mathrm{~mm}$ ), together with 0 . bazarovi Erbajeva, 1988, O. dehmi Erbajeva, 2005, O. mediterranensis Suata Alpaslan, 2009, O. minor Bohlin, 1942, O. polonica Sych, 1990, O. pusilla, O. valerotae Erbajeva et al., 2001, O. zabiensis Fostowicz-Frelik, 2008.

Among these species, the Central Asian step pika O. pusilla is quite common in European Plio-Pleistocene localities. Malatesta (1951), Malez (1969) and Erbajeva et al. (2001) provided a large account of its occurrences in Europe and Asia. Lastly, FostowiczFrelik and Frelik (2010) reported on its occurrence in Poland since the latest Pliocene (locality of Kielniki 3), almost coeval with its first occurrence in Kazakhstan (Aktogai; Erbajeva, 1988). In Turkey, this species was found in two middle-late Pleistocene localities at Yarimburgaz Cave near Istanbul, and Emirkaya-2 fissure filling near Konya (Montuire et al., 1994; Santel and Von Koenigswald, 1998; see also Erbajeva et al., 2001), and Čermák et al. (2006) mentioned its possible occurrence in Güzyurdu Cave near Gümüshane. O. pusilla is a small-sized species, characterized by a very small anteroconid, and reduced paraflexid and protoflexid on the p3. It is hardly compared with the Çeştepe ochotonid.

During the Pliocene and early Pleistocene in Europe, O. polonica is the best-documented species in several localities of Poland. Fostowicz-Frelik (2008) rightly included in this species Ochotona dehmi from the latest Pliocene locality of Schernfeld (Germany) and 0 . valerotae from Les Valerots (early Pleistocene, France). She demonstrated that these two species are similar in size to O. polonica, and their $\mathrm{p} 3$ is elongated, the anteroconid is simple and tapers anteriorly as in 0 . polonica. Indeed, a few differences that the authors showed to distinguish these forms from 0 . polonica are in the range of individual variation. The measurements of mandible and cheek teeth of $O$. polonica are rather similar to that of Çeştepe. However, O. polonica is different from the Çeştepe ochotonid in having mandible with flat ventral margin (curved at Çeştepe), p3 elongated, and its anteroconid elongated and triangular without any grooves and with a sharp apex (Fostowicz-Frelik, 2008). The proportions of the anteroconid and posteroconid on the $\mathrm{p} 3$ are also different. In summary, despite the similarity in size, the morphology of mandible and lower cheek teeth of $O$. polonica are clearly different from that of Çeştepe. 
Fostowicz-Frelik (2008) described another small-sized ochotonid, O. zabiensis, from the early Biharian locality Zabia Cave, Poland. In this species, the ventral margin of the mandible is almost flat and the p3 is elongated with a mesially sharp anteroconid as in 0 . polonica. O. zabiensis is distinguished in having the paraflexid of p3 deeper than protoflexid, different from the condition observed in $O$. polonica as well the Çeştepe pika. This is also the case of 0 . kormosi Fostowicz-Frelik et al., 2010 from the latest Pliocene of Hungary (type loc. Ostramos-3), which is distinguished from the other species by its p3 markedly elongated with a long and narrow posteroconid, and anteroposteriorly compressed anteroconid.

The Çeştepe ochotonid is better compared with Ochotona antiqua Argyropulo and Pidoplichko, 1939 from Novopetrovka (type locality) in Ukraine. Lastly, Čermák and Rekovets (2010) restudied the material from its type locality and from some others in Ukraine. These authors largely discussed the morphological affinities and differences of the type material with other Pliocene species from central and eastern Asia, which were updated by Erbajeva and Zheng (2005) and Erbajeva et al. (2011). The Çeştepe specimens are similar to that of $O$. antiqua from its type locality both in the shape of the mandible and the pattern of cheek teeth, in particular the $\mathrm{p} 3$, and they do not show any reliable difference to be noted. However, the size of the Çeştepe specimens is about $1 / 3$ smaller than $O$. antiqua. O. mediterranensis is known from its type locality of Iğdeli in the Sivas Basin. We agree with Suata Alpaslan (2009) that the pika remains from the early Pliocene locality of Maritsa (island of Rhodos, Greece; De Bruijn et al., 1970) may be included in this species. Both localities are dated to early Pliocene (MN14). This species has also the same characters on its mandible and tooth pattern, but it is clearly smaller and it fits in size with the Çeştepe specimens. Based on the similarities in size, and also the shape of mandible and tooth pattern although shared with $O$. antiqua as discussed above, the Çeştepe specimens are referred to 0 . mediterranensis.

The presence of great morphological resemblances, but a significant difference in size between $O$. mediterranensis and $O$. antiqua recalls the Bergmann's rule that states that species of larger size are found in colder environments, and species of smaller size are found in warmer regions. The known dispersal area of the smaller species 0 . mediterranensis (Iğdeli, Maritsa and Çeştepe) is situated between the latitudes $35-40^{\circ} \mathrm{N}$ while that of 0 . antiqua between the latitudes $45-50^{\circ} \mathrm{N}$ (north of Black Sea and possibly Romania), both during the early Pliocene. Although this hypothesis suggests a possible synonymy of $O$. mediterranensis with $O$. antiqua, we know nothing on the latitudinal size variation in the extant and extinct species of Ochotona, thus preventing to assert such synonymy.

The list of extinct Ochotona species given by Erbajeva et al. (2015) includes two species, O. agadzhaniani Melik-Adamian, 2003 and O. azerica Gadzhiev and Aliev, 1969, both from Armenia. As this territory is neighbor to Turkey, we would compare these species with the Çeştepe specimens. Alexey Tesakov (Geological Institute of the Russian Academy of Sciences, Moscow) gently provided informations dealing with them. "O. agadzhaniani is from the locality of Nurnus (MN14), and it was named in the unpublished thesis of Melik-Adamyan (2003). O. azerica is reported from the famous Azukh or Azokh cave, apparently from upper Ascheulian beds. Its validity is also questionable. The original thesis on mammals from Azykh by Aliev (1969) was not officially published" (Tesakov, in litteris, August 20, 2016; see also Čermák et al., 2006). In summary, both species are nomen nudum, since they are not described and illustrated in a published paper.

\section{History of lagomorphs in Asia Minor}

Since their appearance in early Eocene, the evolutionary history of lagomorphs is shaped by their dispersal all over the three

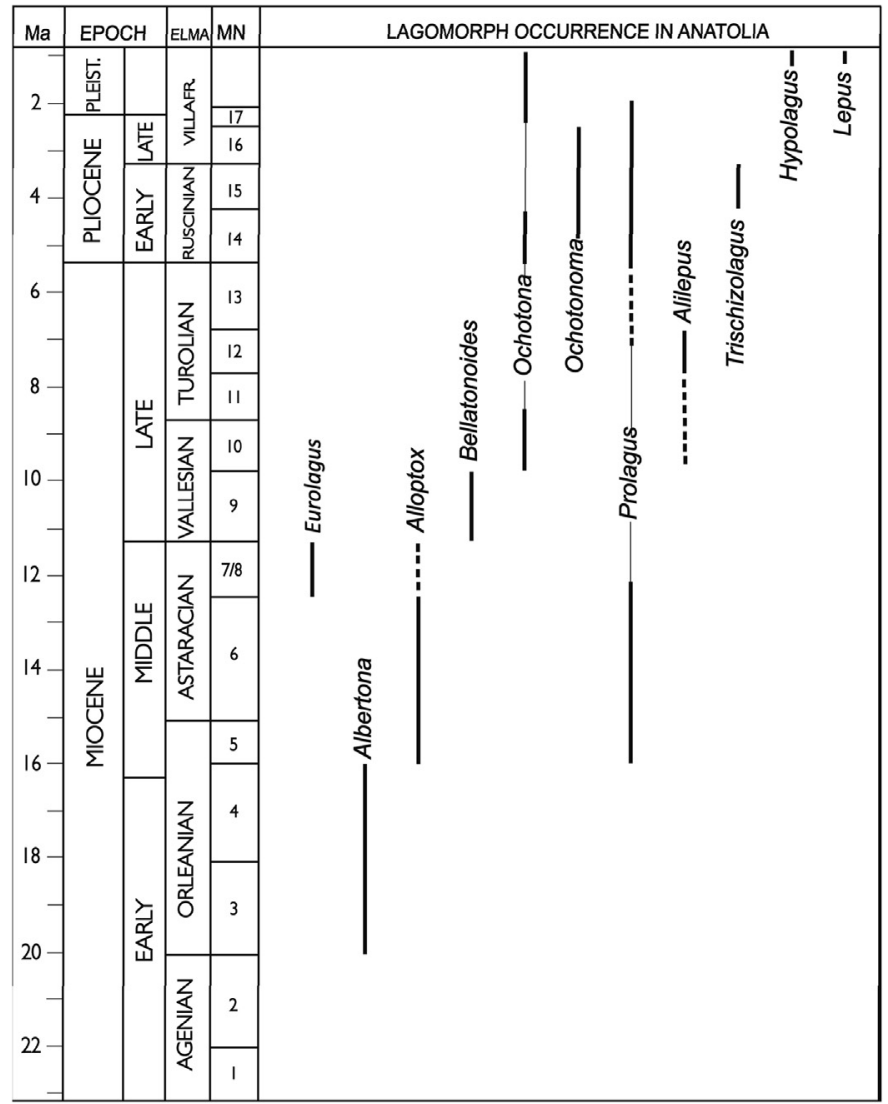

Fig. 8. Time range of fossil lagomorph genera in Anatolia. Distribution temporelle des genres de lagomorphes fossiles en Anatolie.

continents of the Old World (Flynn et al., 2013; Erbajeva et al., 2015). Asia Minor is situated in a central position between these continents and had to play the role of bridge on the dispersal routes of lagomorphs throughout the Cenozoic. Below, we propose a synthesis of available data to highlight the taxa already recognized, and to try an attempt on their paleobiogeographic affinities with other regions of the Old World.

Taking into account all published faunal lists (Sickenberg et al., 1975; Saraç, 2003), NOW Database (Fortelius, 2016), and descriptions in several papers (Ünay and Sen, 1976; Sen et al., 1989; Sen, 1990, 1991, 1998a, 1998b, 2003, 2016; Montuire et al., 1994; Ünay and de Bruijn, 1998; Ünay and Göktaș, 1999; Ünay et al., 2001; De Bruijn et al., 2003, 2006; Suata Alpaslan, 2009), fossil lagomorphs have been recorded in Anatolia in 66 localities aged between early Miocene and middle Pleistocene. The specimens from 19 localities are more or less well described and illustrated to satisfy their identifications at generic and in most cases specific level. It appears that the family Ochotonidae is the best-documented, with six genera (Albertona, Alloptox, Prolagus, Bellatonoides, Ochotonoma and Ochotona) in 48 localities, compared to the Leporidae with four genera (Alilepus, Hypolagus, Trischizolagus and Lepus) in 9 localities, and the Palaeolagidae with one genus (Eurolagus) in 2 localities.

Fig. 8 summarizes the chronological occurrence of fossil lagomorphs in Anatolia during the Neogene and Quaternary. It appears that the earliest lagomorph in Anatolia is referred to the genus Albertona, which is an ochotonid known up to date from Serbia, Greece and Turkey during early Miocene (López-Martínez, 1986; Ünay and Göktaş, 1999; Marković, 2010). In middle Miocene localities, the common genera are Alloptox and Prolagus, which generally co-occur in the same localities (Paşalar, Çandir, Bağiçi, Zambal 2; 
Sen, 1990; De Bruijn et al., 2003; Saraç, 2003), and in similar percentages. Alloptox as Albertona has Asiatic affinities, while Prolagus is mostly a European genus (López-Martínez, 2001).

The history of the genus Prolagus is rather peculiar in Anatolia. It is common in middle Miocene localities, as mentioned above, but totally absent in late Miocene localities, except at Düzyayla and Kangal 1, both in the Sivas Basin, where De Bruijn et al. (1999) and Saraç (2003), respectively, mentioned the occurrence of Prolagus, without further study. These identifications need to be verified. Prolagus is not recorded in the well-documented Sinap Formation localities that cover the time interval 8-11 Ma. Prolagus "reappears" in the Pliocene faunas of Anatolia. For instance, it is quite common and the unique ochotonid in the western Anatolian localities of Develi and Halitpasa (Sen et al., 1989; Kaya et al., 2004), while in eastern Anatolia it co-occurs at Iğdeli (MN14, Sivas Basin) together with Ochotona (Suata Alpaslan, 2009; Suata Alpaslan et al., 2010), and it is absent at Çalta (MN15, Kazan Basin). We have to remember that Prolagus is widely distributed mostly in Europe, and that Anatolia is in the southeastern borders of its dispersal area. Thus, it is quite likely that the occurrence of Prolagus in the Pliocene of Anatolia can be qualified as a Lazarus event.

Lagomorphs are absent around the middle-late Miocene boundary in the well-documented Sinap Formation localities in the Kazan area. Their first occurrence is dated to $9.9 \mathrm{Ma}$ at Sinap Loc. $8 \mathrm{~A}$ with Bellatonoides eroli. From the late Miocene upwards, the genera of the "Ochotona group" (sensu Sen, 2003; i.e. Bellatonoides, Ochotona and Ochotonoma) replace the couple Alloptox-Prolagus of the middle Miocene. All three genera have clearly Asian affinities. Ochotona ozansoyi from Sinap Loc. 84, dated to 9.4 Ma by magnetostratigraphy (Kappelman et al., 2003) is the oldest species referred to this genus. It is also recorded in another locality in Central Anatolia (cf. at Inönü; Sen, 2003) and at Küçükçekmece near Istanbul (Sen, 2016), both correlated to the late Vallesian. We have to mention here that Erbajeva et al. (2015) suggested to refer O. ozansoyi to the genus Proochotona Khomenko, 1914, known with Proochotona eximia Khomenko, 1914 from the late Miocene (early Turolian) locality of Tarakliya in Moldova. The status of the genus Proochotona is still debated (Sen, 2003; Erbajeva et al., 2011, 2015; Delinschi, 2014; Čermák, 2016). This taxonomic problem needs further study on the material of its type locality and also additional material from similar age localities.

During the Turolian, lagomorphs seem to be absent or extremely discrete in Anatolia, but this is probably due to insufficient fossil record. Indeed, Turolian localities in Turkey are mainly known for their large mammals, except a few localities from which small mammals are documented (e.g., Çorakyerler, Karaözü, Kaleköy) otherwise than preliminary identifications.

The genus Ochotona reappears in Anatolia in early Pliocene (Suata Alpaslan, 2009), and became probably extinct during the historical times (Čermák et al., 2006).

Leporids are poorly documented in Anatolia, as seen on Fig. 8. The oldest record is a lower molariform tooth from Sinap Tepe Loc 12 referred to Leporidae indet. (Sen, 2003). This is a surface finding, and consequently its age may be different from that of this locality, which is dated by magnetostratigraphy at $9.6 \mathrm{Ma}$ (Kappelman et al., 2003). The genera Trischizolagus, Hypolagus and Lepus are known each from one locality (Tozaklar, Emirkaya 2, Dursunlu, respectively), and the genus Alilepus is mentioned in two localities (Düzyayla and Halitpasa; De Bruijn et al., 1999; Saraç, 2003).

In summary, the state of the art shows that the family of Ochotonidae is well-documented in Turkey, while the record dealing with the Leporidae is poor. The record is rich for some intervals of Neogene (e.g. middle Miocene, early late Miocene, early Pliocene) and still sparce for other intervals. When accurately studied, the Lagomorpha effectively contribute to the dating of fossiliferous deposits and to the environmental context of mammalian faunas.
Although poor, the Çeştepe faunule provides a good example for this.

\section{Conclusions}

Sedimentary deposits are the archives of the past. In the eastern part of the Kazan Basin (NW to Ankara), sedimentary deposits of the Sinap Formation are richly fossiliferous and documented Neogene mammalian faunas. A new locality at the village of Çeştepe, in the northeastern margin of this basin, provides a new landmark to document the stratigraphy. The fossil material consists of fragmented bones and jaws. We identified three species of reptiles (cf. Lacerta sp., Anguinae indet. and Varanus sp.) and an ochotonid lagomorph, Ochotona mediterranensis. The occurrence of the latter species, previously known from the localities of Iğdeli in the Sivas Basin and Maritsa in the island of Rhodes (Greece), suggests the correlation of this locality to early Ruscinian (early Pliocene, MN14)(De Bruijn et al., 1970; Suata Alpaslan, 2009). Among these taxa, both Varanus and Ochotona were previously recorded in the same basin, but in different stratigraphic horizons. The only locality in Turkey from which Varanus remains are described is Çalta, at $16.5 \mathrm{~km} \mathrm{SW}$ to Çeştepe (Rage and Sen, 1976). This locality is a little younger than Çeştepe, correlated to the late Ruscinian (MN15). Also, two localities in the Kazan Basin yielded the remains of an ochotonid, Ochotona ozansoyi Sen, 2003 from two sites dated to the late Vallesian (MN10). This species is different from that of Çeştepe, having a larger size, smaller and simple-shaped anteroconid and shorter posterior segment on the p3, and curved cheek teeth. The specimens from Çeştepe fit in the shape of the lower jaw and the pattern of cheek teeth with $O$. mediterranensis. Morphological similarities between this species and $O$. antiqua from the northern rims of Black Sea should be noted, although 0 . mediterranensis is $1 / 3$ smaller.

The faunule from Çeştepe includes only Eurasian taxa. However, it must be noted that this assemblage is biased by collecting technique. It is far from reflecting the spectrum of an early Pliocene fauna, and it is hardly compared with faunas of similar age, which limits its paleobiogeographic and environmental significance. Although the genus Ochotona had, during the Pleistocene, a large spatial range from the Pyrenees and southern England to eastern China, it is now mainly considered as an Asiatic element adapted to steppic environments with low vegetation. Its extant species live on rocky mountainsides to find shelter in crevices. In Turkey, the genus survived during the Pleistocene, but apparently become extinct in Holocene (Čermák et al., 2006). This study evidences that the fossil record in terrestrial deposits, although limited in the number of taxa as it is the case in the present study (just three reptiles and one ochotonid), contributes to document the history of these groups, and beyond this, it provides biochronological and environmental data for the related deposits.

\section{Disclosure of interest}

The authors declare that they have no competing interest.

\section{Acknowledgements}

Adem Akköprü (ASKI-Water Works Office of Ankara Metropol Municipality) is the author of the discovery of vertebrate fossils at Çeştepe. He stopped the excavation when seeing the fossils and informed N. Kazanci. Yaşar Suludere (JRMIRKO-Turkish Association for Conservation of Geoheritage), Baki Varol, Ezgi Güllü, Özgür Yedek, Türkan Akçalar (Ankara University) visited the site and collected fossils. Hilal Engin Dokuz and Alper Gürbüz (Ankara University) helped with drawing of geological maps. Philippe Loubry (CNRS, Muséum) made the photos of lagomorphs. M.D. 
was supported by Università di Torino (Fondi di Ateneo 2014, 2015) Generalitat de Catalunya (2014 SGR 416 GRC) and CERCA Program, and Spanish Ministerio de Economía y Competitividad (CGL2016-76431- P). G. Georgalis and A. Villa provided valuable comments on the reptiles and Stanislav Čermák and Alexey Tesakov on the lagomorphs. The comments and suggestions of the referees Chiara Angelone and Hugues-Alexandre Blain, and of the editor Didier Néraudeau, were very useful to improve this paper. We are grateful to all of them.

\section{References}

Adıgüzel, N., Vural, M., 1995. Vegetation of Soğuksu National Park (Ankara). Turkish Journal of Botany 19, 213-234.

Aliev, S.D., (Dissertation Thesis, unpublished) 1969. Fauna Azyhskoj paleolitičeskoj stojanki [Fauna of the Palaeolithic Azyh encampment]. Institute of Zoology, Baku (30 p. In Russian).

Alpagut, B., Andrews, P., Fortelius, M., Kappelman, J., Temizsoy, İ., Çeelebi, H., Lindsay, W., 1996. A new specimen of Ankarapithecus meteai from the Sinap Formation of Central Anatolia. Nature 382, 349-351.

Arnold, E.N., 1973. Relationships of the Palaearctic lizards assigned to the genera Lacerta, Algyroides and Psammodromus (Reptilia, Lacertidae). Bulletin of the British Museum Natural History Zoology 25, 289-366.

Arnold, E.N., 1989. Towards a phylogeny and biogeography of the Lacertidae: relationship within an Old World family of lizards derived from morphology. Bulletin of the British Museum Natural History Zoology 55, 209-257.

Arnold, E.N., Arribas, O., Carranza, S., 2007. Systematics of the Palaearctic and Oriental lizard tribe Lacertini (Squamata: Lacertidae: Lacertinae), with descriptions of eight new genera. Zootaxa 1430, 1-86.

Atabey, E., Saraç, G., 2004. Ankara Çamlıdere tașlașmıș ağaç fosil ormanı. TMMOB Jeoloji Mühendisleri Odası Haber Bülteni 3, 80-82.

Augé, M., Rage, J.C., 2000. Les Squamates (Reptilia) du Miocène moyen de Sansan. In: Ginsburg L. (Ed.), La faune miocène de Sansan et son environnement. Mémoires du Muséum National d'Histoire Naturelle 183, 263-313.

Bailey, E.B., McCallien, W.S., 1953. The Ankara Mélange and Anatolia Thrust. Nature 166, 938-941.

Barahona, F., Barbadillo, L.J., 1997. Identification of some Iberian lacertids using skull characters. Revista Española de Herpetología 11, 47-62.

Barbadillo, L.J., Sanz, J.L., 1983. Análisis osteometrico de las regiones sacra y presacra de la columna vertebral en los lagartos ibéricos Lacerta viridis Laurenti, Lacerta lepida Daudin y Lacerta schreiberi Bedriaga. Amphibia-Reptilia 4, 215-239.

Blain, H.A., 2016. Chapter 9. Amphibians and Squamate Reptiles from Azokh 1. In: Fernández-Jalvo, Y., King, T., Yepiskoposyan, L., Andrews, P. (Eds.), Azokh Cave and the Transcaucasian Corridor, Vertebrate Paleobiology and Paleoanthropology Series. Springer, pp. 191-210.

Blain, H.A., Agustí, J., Lordkipanidze, D., Rook, L., Delfino, M., 2014. Paleoclimatic and paleoenvironmental context of the early Pleistocene hominins from Dmanisi (Georgia, Lesser Caucasus) inferred from the herpetofaunal assemblage. Quaternary Science Reviews 105, 136-150.

Böhme, M., Ilg, A., 2003. fosFARbase (Accessed 31.08.2016) http://www.wahrestaerke.com/.

Čermák, S., 2010. The late Miocene and Pliocene Ochotoninae (Lagomorpha, Mammalia) of Europe - the present state of knowledge. In: Nowakowski, D. (Ed.), Morphology and Systematics of Fossil Vertebrates. DN Publisher, Wroclaw, Poland, pp. 9-28.

Čermák, S., 2016. The late Miocene species Ochotona kalfense (Mammalia, Lagomorpha) of Moldova: the oldest European record of the genus in the context of the earliest Ochotoninae. Comptes Rendus Palevol 15, 927-940.

Čermák, S., Rekovets, L.I., 2010. Early Pliocene ochotonids (Mammalia, Lagomorpha) from Southern Ukraine. Geodiversitas 32 (1), 107-120.

Čermák, S., Obuch, J., Benda, P., 2006. Notes on the genus Ochotona in the Middle East (Lagomorpha: Ochotonidae). Lynx 37, 51-66.

Colombero, S., Angelone, C., Bonelli, E., Carnevale, G., Cavallo, O., Delfino, M., Giuntelli, P., Mazza, P., Pavia, G., Pavia, M., Repetto, G., 2014. The Messinian vertebrate assemblages of Verduno (NW Italy): another brick for a latest Miocene bridge across the Mediterranean. Neues Jahrbuch für Geologie und PaläontologieAbhandlungen 272 (3), 287-324.

Colombero, S., Alba, D.M., D’Amico, C., Delfino, M., Esu, D., Giuntelli, P., Harzhauser, M., Mazza, P.P.A., Mosca, M., Neubauer, T.A., Pavia, G., Pavia, M., Villa, A., Carnevale, G., 2017. Late Messinian mollusks and vertebrates from Moncucco Torinese, northwestern Italy. Paleoecological and paleoclimatological implications. Palaeontologia Electronica (in press)

De Bruijn, H., Dawson, M.R., Mein, P., 1970. Upper Pliocene Rodentia, Lagomorpha and Insectivora (Mammalia) from the Island of Rhodes (Greece). Proceedings of Koninklijke Nederlandse Akademie van Wetenschappen B 73, 314-338.

De Bruijn, H., Saraç, G., Van den Hoek Ostende, L.W., Roussiakis, S., 1999. The status of the genus name Parapodemus Shaub, 1938; new data bearing on an old controversy. In: Reumer, J.W.F., De Vos, J. (Eds.), Elephants have a snorkel! Papers in honour of Paul Y. Sondaar. Deinsea 7, 95-112.

De Bruijn, H., Van den Hoek Ostende, L., Kristkoiz-Boon, E., Rummel, M., Theocharopoulos, C., Ünay, E., 2003. Rodents, lagomorphs and insectivores, from the middle Miocene hominoid locality of Çandır (Turkey). In: Güleç, E., Begun, D., Geraads, D. (Eds.), Geology and Vertebrate Paleontology of the Middle Miocene Hominoid Locality Çandır (Central Anatolia, Turkey). Courier Forschungsinstitut Senckenberg 240, 51-89.

De Bruijn, H., Mayda, S., Van den Hoek Ostende, L., Kaya, T., Saraç, G., 2006. Small mammals from the Early Miocene of Sabuncubeli (Manisa, S.W. Anatolia, Turkey). Beiträge zur Paläontologie 30, 57-87.

Delfino, M., Rage, J.-C., Bolet, A., Alba, D.M., 2013. Early Miocene dispersal of the lizard Varanus into Europe: reassessment of vertebral material from Spain. Acta Palaeontologica Polonica 58, 731-735.

Delinschi, A., 2014. Late Miocene lagomorphs from the Republic of Moldova. Annales de Paléontologie 100, 157-163.

Dilek, Y., Thy, P., 2006. Age and petrogenesis of plagiogranite intrusions in the Ankara Mélange, Central Turkey. Island Arc 15, 44-57.

Dirik, K., Erol, O., 2000. Tuzgölüi ve civarının tektonomorfolojik evrimi, Orta Anadolu, Türkiye. Haymana - Tuzgölü - Ulukışla Basenleri Uygulamalı Çalışma (Workshop). Türkiye Petrol Jeologları Derneği, Özel Sayı 5, 27-46.

Duru, M., Aksay, A., 2002. 1/100,000 ölçekli Türkiye Jeoloji Haritaları No. 42 Bolu H29 Paftası. Maden Tetkik ve Arama Genel Müdürlüğü, Ankara. (25 p.).

Erbajeva, M.A., 1988. Cenozoic Pikas (Taxonomy, Systematics, Phylogeny). Nauka, Moscow (224 p. In Russian).

Erbajeva, M.A., 1994. Phylogeny and evolution of Ochotonidae with emphasis on Asian ochotonids. In: Tomida, Y., Li, C.K., Setoguchi, T. (Eds.), Rodent and Lagomorph Families of Asian Origins and Diversification. National Science Museum Monographs Tokyo 8, 1-13.

Erbajeva, M.A., 2005. New Late Pliocene pika (Lagomorpha, Mammalia) from Germany. Paleontological Journal 3, 91-93.

Erbajeva, M., Flynn, L.J., Alexeeva, N., 2015. Late Cenozoic Asian Ochotonidae: taxonomic diversity, chronological distribution and biostratigraphy. Quaternary International 355, 18-23.

Erbajeva, M.A., Mead, J.I., Alexeeva, N.V., Angelone, C., Swift, S.L., 2011. Taxonomic diversity of late Cenozoic Asian and North American ochotonids (an overview). Palaeontologia Electronica 14 (3), 42A (9 p.; palaeo - electronica.org/2011_3/25_erbajeva/index.html).

Erbajeva, M.A., Montuire, S., Chaline, J., 2001. New ochotonids (Lagomorpha) from the Pleistocene of France. Geodiversitas 23 (3), 395-409.

Erbajeva, M.A., Zheng, S., 2005. New data on late Miocene-Pleistocene ochotonids (Ochotonidae, Lagomorpha) from North China. Acta zoologica cracoviensia 48 (1-2), 93-117.

Erişen, B., Ünlü, M.R., 1976. Ankara Çubuk-Kızılcahamam-Kazan alanının jeolojisi ve jeotermal olanakları. MTA Report, No. 9949, Ankara. (Unpublished).

Erol, O., Yurdakul, E., Algan, Ü., Gürel, N., Herece, E., Tekirli, E., Ünsal, Y., Yüksel, M., 1980. Ankara metropoliten arazi kullanım haritası. MTA Report, Ankara. (99 p. Unpublished).

Flynn, L.J., Winkler, A.J., Erbaeva, M., Alexeeva, N., Anders, U., Angelone, C., Čermák, S., Fladerer, F.A., Kraatz, B., Ruedas, L.A., Ruf, I., Tomida, Y., Veitschegger, K., Zhang, Z., 2013. The Leporid Datum: a late Miocene biotic marker. Mammal Review 44 (3-4), 164-176.

Fortelius, M. (coordinator) (Ed.), 2016. Neogene of the Old World Database of Fossil Mammals (NOW). University of Helsinki http://www.helsinki.fi/science/now/.

Fortelius, M., Kappelman, J., Sen, S., Bernor, R.L. (Eds.), 2003. Geology and Paleontology of the Miocene Sinap Formation, Turkey. Columbia University Press, New York (409 p.).

Fostowicz-Frelik, Ł., 2008. Review of the earliest Central European Ochotona (Mammalia: Lagomorpha), with description of a new species from Poland. Mammalia $72,71-81$.

Fostowicz-Frelik, Ł., Frelik, G.J., 2010. The earliest occurrence of the steppe pika (Ochotona pusilla) in Europe near the Pliocene/Pleistocene boundary. Naturwissenschaften 97 (3), 325-329.

Fostowicz-Frelik, Ł., Frelik, G.J., Gasparik, M., 2010. Morphological phylogeny of pikas (Lagomorpha: Ochotona), with a description of a new species from the Pliocene/Pleistocene transition of Hungary. Proceedings of the Academy of Natural Sciences of Philadelphia 159 (1), 97-118.

Ge, D., Wen, Z., Xia, L., Zhang, Z., Erbajeva, M., Huang, C., Yang, Q., 2013. Evolutionary history of lagomorphs in response to global environmental change. Plos One 8 (4), $1-15$.

Gökten, E., Kazancı, N., Acar, S., 1988. Ankara kuzeybatısında (Bağlum-Kazan arası) geç Kretase-Pliyosen serilerinin stratigrafisi ve tektoniği. MTA Bulletin 108, 69-81.

Görür, N., Tüysüz, O., Şengör, A.M.C., 1998. Tectonic evolution of the Central Anatolian basins. International Geology Review 40, 831-850.

Hatipoğlu, M., Türk, N., 2009. A combined polarizing microscope, XRD, SEM, and specific gravity study of the petrified woods of volcanic origin from the Camlıdere-Celtikci-Güdül fossil forest, in Ankara, Turkey. Journal of African Earth Sciences 53, 141-157.

Hoffmann, R.S., Smith, A.T., 2005. Order Lagomorpha. In: Wilson, D.E., Reeder, D.M. (Eds.), Mammal Species of the World: A Taxonomic and Geographic Reference 1. The John Hopkins University Press, Baltimore, Maryland, pp. 185-211.

Inci, U., Helvacı, C., Yağmurlu, F., 1986. Stratigraphy of Beypazari Neogene Basin, Central Anatolia, Turkey. Newsletters on Stratigraphy 18 (3), 165-182.

Kahraman, C., (Ms Thesis) 2014. Hydrogeological Characterization and Investigation of the Çeltikçi Coal Basin in Central Anatolia. Middle East Technical University, Ankara (211 p. Unpublished).

Kappelman, J., Duncan, A., Feseha, M., Lunkka, J.-P., McDowell, F., Ryan, T.M., Swisher III., C.C., 2003. Chronology. In: Fortelius, M., Kappelman, J., Sen, S., Bernor, 
R.L. (Eds.), Geology and Paleontology of the Miocene Sinap Formation, Turkey. Columbia University Press, New York, pp. 41-66.

Karaca, A., (Ms Thesis) 2004. Post-Miocene Deformation of the Area Between Alibey (Kizilcahamam) and Karalar (Kazan) Villages, NW Ankara (Turkey). Middle East Technical University, Ankara (100 p. Unpublished).

Karadenizli, L., 1995. Beypazarı havzası (Ankara batısı) Üst Miyosen-Pliyosen jipsli serilerinin sedimantolojisi. Türkiye Jeoloji Bülteni 38, 63-74.

Karadenizli, L., 2011. Oligocene to Pliocene palaeogeographic evolution of the Çankiri-Çorum Basin, central Anatolia, Turkey. Sedimentary Geology 237, 1-29.

Karadenizli, L., Seyitoğlu, G., Saraç, G., Kazancı, N., Şen, Ş., Hakyemez, Y., Savaşçı, D., 2003. Early Middle Miocene palaeogeographic evolution of the western margin of Çankırı-Çorum Basin, Central Anatolia, Turkey. Bulletin of Mineral Research and Exploration 126, 69-86.

Kasaplıgil, B., 1977. Ankara-Kızılcahamam yakınındaki Güvem Köyü civarında bulunan son Tersiyer kozalaklı-yeşil yapraklı ormanı. MTA Dergisi 88, 94-122.

Kaya, O., Ünay, E., Saraç, G., Eichhorn, S., Hassenrück, S., Knappe, A., Pekdeger, A., Mayda, S., 2004. Halitpaşa transpressive zone: implications for an early Pliocene compressional phase in central western Anatolia, Turkey. Turkish Journal of Earth Sciences 13 (1), 1-13.

Kaymakçı, N., 2000. Tectono-stratigraphical evolution of the Çankırı Basin (Central Anatolia, Turkey). Geologia Ultraiectina 190, 1-247.

Kazancı, N., 2012. Geological background and three vulnerable geosites of the Kızılcahamam - Çamlıdere Geopark Project in Ankara, Turkey. Geoheritage 4, 249-261.

Kazancı, N., Şen, S., Seyitoğlu, G., de Bonis, L., Bouvrain, G., Araz, H., Varol, B., Karadenizli, L., 1999. Geology of a new late Miocene mammal locality in Central Anatolia, Turkey. Comptes Rendus de l'Academie des Sciences IIa - Earth and Planetary Sciences 329, 503-510.

Kazancı, N., Suludere, Y., Mülazımoğlu, N.S., Tuzcu, S., Mengi, H., Hakyemez, Y., Mercan, N., 2007. Milli Parklarda Jeomiras 1. Soğuksu Milli Parkı ve Çevresi Jeositleri. Doğa Koruma ve Milli Parklar Genel Müdürlügü ve jeolojik Mirası Koruma Derneği, Ankara (60 p.)

Klembara, J., 2012. A new species of Pseudopus (Squamata, Anguidae) from the early Miocene of Northwest Bohemia (Czech Republic). Journal of Vertebrate Paleontology 32, 854-866.

Klembara, J., Böhme, M., Rummel, M., 2010. Revision of the anguid lizard Pseudopus laurillardi (Squamata, Anguidae) from the Miocene of Europe, with comments on palaeoecology. Journal of Paleontology 84, 159-196.

Klembara, J., Miroslav, J., Dobiašová, K., 2014. Comparative anatomy of the lower jaw and dentition of Pseudopus apodus and the interrelationships of species of subfamily Anguinae (Anguimorpha, Anguidae). The Anatomical Record 297, 516-544.

Koçyiğit, A., Özkan, S., Rojay, B., 1988. Examples from the forearc basin remnants at the active margin of northern Neotethys; development and emplacement ages of the Anatolian Nappe, Turkey. METU Journal of Pure and Applied Sciences 21 (1-3), 183-210.

Koçyiğit, A., Rojay, B., Cihan, M., Özacar, A., 2001. The June 6, 2000, Orta (Çankırı, Turkey) earthquake: Sourced from a new antithetic sinistral strike-slip structure of the North Anatolian Fault System, the Dodurga Fault Zone. Turkish Journal of Earth Sciences 10, 69-82.

Lissovsky, A.A., 2014. Taxonomic revision of pikas Ochotona (Lagomorpha, Mammalia) at the species level. Mammalia 78 (2), 199-216.

Lopez-Antoñanzas, R., Sen, S., Saraç, G., 2004. A new large ctenodactylid species from the Lower Miocene of Turkey. Journal of Vertebrate Paleontology 24, 676-688.

López-Martínez, N., 1989. Revision sistemática y biostratigráfica de los Lagomorpha (Mammalia) de Terciario y Cuaternario de España. Memorias del Museo Paleontológico de la Universidad de Zaragoza 3 (3), 1-296.

Lunkka, J.P., Kappelman, J., Ekart, D., Crabaugh, J., Gibbard, P., 2003. Geology. In: Fortelius, M., Kappelman, J., Sen, S., Bernor, R.L. (Eds.), Geology and Paleontology of the Miocene Sinap Formation, Turkey. Columbia University Press, New York, pp. 26-40.

Malatesta, A., 1951. Considerazioni sugli Ochotonidae fossili e viventi. Bolletino del Servizio Geologico Italia 71, 121-146.

Malez, M., 1969. Diffusione del genere Ochotona nel Pleistocene superiore dell'Europa sud-orientale. Museo civico di Storia naturale di Verona, Memorie fuori Serie 3, 67-73.

Marković, Z., 2010. Albertona balkanica from Early Miocene of Snegotin (Serbia) - implications for the distribution and evolution of Miocene Ochotonidae. Annales de Paléontologie 96 (2), 25-32.

Melik-Adamyan, G., (Abridged thesis) 2003. Stratigraphy and Paleogeography of Pliocene and Lower Neopleistocene of Central and Northwestern Armenia based on Fauna of Land Vertebrates. Cand. Sci., Erevan (29 p. Unpublished).

Montuire, S., Sen, S., Michaux, J., 1994. The middle Pleistocene mammalian fauna from Emirkaya-2, Central Anatolia (Turkey): systematics and paleoenvironment. Neues Jahrbuch für Geologie und Paläontologie-Abhandlungen 193, 107-144.

MTA, 2002. Ankara sheet of $1 / 500,000$ geological maps of Turkey. A publication of General Directorate of Mineral Research and Exploration of Turkey, Ankara.

Okay, A.I., Göncüoglu, M.C., 2004. Karakaya complex: a review of data and concepts. Turkish Journal of Earth Sciences 13, 77-95.

Öngür, T., 1976. Kızılcahamam, Çamlıdere, Çeltikçi, Kazan dolayının jeoloji durumu ve jeotermal enerji olanakları, MTA Ankara, Report No. 3273. (34 p. Unpublished).

Ozansoy, F., 1965. Étude des gisements continentaux et des mammifères du Cénozoïque de Turquie. Mémoires de la Société Géologique de France 102, 1-92.

Rage, J.C., Sen, S., 1976. Les amphibiens et les reptiles du Pliocène supérieur de Çalta (Turquie). Géologie Méditerranéenne 3, 127-134.
Roček, Z., 1980. The dentition of the European Glass Lizard Ophisaurus apodus (Pallas 1775) (Reptilia, Sauria: Anguidae), with notes on the pattern of tooth replacement. Amphibia-Reptilia 1, 19-27.

Rojay, B., 2013. Structural Evolution of Celtikçi - Gümele Area During Post-Miocene. A Technical Report. Middle East Technical University, Ankara (38 p. Unpublished).

Rojay, B., Karaca, A., 2008. Post-Miocene deformation in the south of the Galatean Volcanic Province, NW of Central Anatolia (Turkey). Turkish Journal of Earth Sciences 17, 653-672.

Rückert-Ülkümen, N., Maus, M., Glav, F., Franzen, M., 2002. Kaulquappen von Pelobates sp. (Amphibia: Pelobatidae) aus dem Miozän von Beşkonak Köyü, Zentralanatolien, Türkei. Bayerische Staatssammlung für Paläontologie und Historische Geologie 42, 75-82.

Ruprecht, K.H., 1956. 1/25,000 ölçekli sayısal jeoloji haritaları Bolu H29-b2 paftası. Türkiye Jeoloji Veri Tabanı. Jeoloji Etüdleri Dairesi Başkanlığı, Maden Tetkik ve Arama Genel Müdürlüğü, Ankara.

Santel, W., Von Koenigswald, W., 1998. Preliminary report on the middle Pleistocene small mammal fauna from Yarimburgaz Cave in Turkish Thrace. Eiszeitalter und Gegenwart 48, 162-169.

Saraç, G., 2003. Türkiye Omurgalı Fosil Yatakları. MTA Report, No. 10609 (218 p. Unpublished).

Sen, S., 1990. Middle Miocene lagomorphs from Paşalar, Turkey. Journal of Human Evolution 19 (4), 455-461.

Sen, S., 1991. Stratigraphie, faunes de mammifères et magnétostratigraphie du Néogène de Sinap Tepe, Province d'Ankara, Turquie. Bulletin du Muséum national d'Histoire naturelle, Paris $4^{\text {e }}$ sér. C (3-4), 243-277.

Sen, S., 1998a. Pliocene vertebrate locality of Çalta, Ankara, Turkey. Geodiversitas 20 (3), 325-510.

Sen, S., 1998b. Rodentia and Lagomorpha. In Sen, S. (Ed.), Pliocene vertebrate locality of Çalta, Ankara, Turkey. Geodiversitas 20 (3), 359-378.

Sen, S., 2003. Lagomorpha. In: Fortelius, M., Kapppelman, J., Sen, S., Bernor, R.L. (Eds.), Geology and Paleontology of the Miocene Sinap Formation, Turkey. Columbia University Press, New York, pp. 163-178.

Sen, S., 2016. Rodents, lagomorphs and insectivores. In: Sen, S. (Ed.), Late Miocene mammal locality of Küçükçekmece, European Turkey. Geodiversitas 38 (2), 299-314.

Sen, S., Rage, J.C., 1979. Çalta (Ankara) Pliyosen omurgalı faunası. Türkiye Jeoloji Kurumu Bülteni 22 (1), 155-160.

Sen, S., Jaeger, J.-J., Dalfes, N., Mazin, J.-M., Bocherens, H., 1989. Découverte d'une faune de petits mammifères pliocènes en Anatolie occidentale. Comptes Rendus de l'Académie des Sciences 309, 1729-1734.

Sengör, A.M.C., 2003. The repeated rediscovery of mélanges and its implications for the possibility and the role of objective evidence in the scientific enterprise. In: Dilek, Y., Newcomb, S. (Eds.), Ophiolite Concept and the Evolution of Geological Thought. Geological Society of America Special Paper 373, $385-445$.

Sengör, A.M.C., Tüysüz, O., Imren, C., Sakınç, M., Eyidogan, H., Görür, N., Le Pichon X., Rangin, C., 2005. The North Anatolian Fault: a new look. Annual Review of Earth and Planetary Sciences 33, 37-112.

Seyitoğlu, G., Aktuğ, B., Karadenizli, L., Kaypak, B., Sen, S., Kazancı, N., Işık, V., Esat, K. Parlak, O., Varol, B., Saraç, G., İleri, İ., 2009. Late Pliocene - Quaternary pinched crustal wedge in NW Central Anatolia, Turkey: a neotectonic structure accommodating the internal deformation of the Anatolian plate. Geological Bulletin of Turkey 52, 121-154.

Sickenberg, O., Becker-Platen, J.D., Benda, L., Berg, D., Engesser, B., Gaziry, W., Heissig, K., Hünermann, K., Sondaar, P.Y., Schmidt-Kittler, N., Staesche, K., Staesche, U. Steffens, P., 1975. Die Gliederung des höheren Jungtertiärs und Altquartärs in der Türkei nach Vertebraten und ihre Bedeutung für die International Neogenstratigraphie. Geologisches Jahrbuch B15, 1-167.

Sindaco, R., Jeremcenko, V., 2008. The Reptiles of the Western Palearctic. 1. Annotated Checklist and Distributional Atlas of the Turtles, Crocodiles, Amphisbaenians and Lizards of Europe, North Africa, Middle East and Centra Asia. Monografie della Societas Herpetologica Italica I. Latina, Belvedere (580 p.)

Smith, K.T., Bhullar, B.-A.S., Holroyd, P.A., 2008. Earliest African record of the Varanus stem-clade (Squamata: Varanidae) from the early Oligocene of Egypt. Journal of Vertebrate Paleontology 28, 909-913.

Suata Alpaslan, F., 2009. Ochotona mediterranensis nov. sp. (Lagomorpha-Mammalia) from early Pliocene of Iğdeli (Anatolia, Turkey). In: 9th International Multidisciplinary Scientific GeoConference SGEM2009 1, pp. 99-103.

Suata Alpaslan, F., Ünay, E., Ay, F., 2010. Iğdeli (Gemerek, Sivas) lokalitesi erken Pliyosen fauna istifinin Rodentia ve Lagomorpha (Mammalia) fosilleri: Biyokronolojik ve paleobiyocografik anlamlari. C.Ü. Fen-Edebiyat Fakültesi, Fen Bilimleri Dergisi 31 (1), 1-29.

Tankut, A., Wilson, M., Yihunie, T., 1998. Geochemistry and tectonic setting of Tertiary volcanism in the Güvem area, Anatolia, Turkey. Journal of Volcanology and Geothermal Research 85, 285-301.

Tatlı, S., 1975. Kızılcahamam Doğu Alanının Jeolojisi ve Jeotermal Enerji Olanakları. MTA report, Ankara, No. 5749. (42 p. Unpublished).

Tekeli, O., 1981. Subduction complex of pre-Jurassic age, Northern Anatolia, Turkey. Geology 9, 68-72.

Toori, M.R., (Ms Thesis) 2005. Orhaniye ve Civari'nin (KKB Ankara-Türkiye) Neojen Stratigrafisi ve Tektoniği. Hacettepe Univ. Fen Bilimleri Enstitüsü, Ankara (76 p. Unpublished).

Toprak, V., Savaşçın, Y., Güleç, N., Tankut, A., 1996. Structure of the Galatia Volcanic Province. International Geology Review 38, 747-758. 
Türkecan, A., Dinçel, A., Hepsen, N., Papak, İ., Akbas, B., Sevin, M., Özgür, İ.B., Bedi, Y., Mutlu, G., Sevin, D., Ünay, E., Saraç, G., Karataş, S., 1991. Bolu-Çankırı (Köroğlu Dağları) arasındaki Neojen yaşlı volkanitlerin stratigrafisi ve petrolojisi. Türkiye Jeoloji Kurumu Bülteni 6, 85-103.

Uetz, P., Freed, P., Hošek, J., 2016. The Reptile Database (Accessed 31.08.2016) http://www.reptile-database.org.

Ünay, E., de Bruijn, H., 1998. Plio-Pleistocene rodents and lagomorphs from Anatolia. Mededelingen Nederlands Instituut voor Toegepaste Geowetenschappen TNO 60, 431-466

Ünay, E., Göktaș, E., 1999. Söke havzasının geç Erken Miyosen ve Kuvaterner yașlı kücük memelileri: ön sonuçlar. Türkiye Jeoloji Kurumu Bülteni 42 (2), 99-115.

Ünay, E., Sen, S., 1976. Une nouvelle espèce d'Alloptox (Lagomorpha, Mammalia) dans le Tortonien d'Anatolie. Bulletin of the Mineral Research and Exploration Institute of Turkey 85, 145-149.

Ünay, E., Atabey, E., Saraç, G., 2001. Small mammals and foraminifera from the Anatolian (Central Taurus) early Miocene. Annals of Carnegie Museum 70 (4), 247-256.

Ünay, E., de Bruijn, H., Saraç, G., 2003. A preliminary zonation of the continental Neogene of Anatolia based on rodents. In: Reumer, J.W.F., Wessels, W. (Eds.), Distribution and migration of Tertiary mammals in Eurasia. A volume in honour of Hans de Bruijn. Deinsea 10, 539-547.
Uyar, G., Çetin, B., 2001. The moss flora of Ankara-Kızılcahamam Soğuksu National Park. Turkish Journal of Botany 25, 261-273.

Van den Hoek Ostende, L.W., Diepeveen, F., Tesakov, A., Saraç, G., Mayhew, D. Alçiçek, M.C., 2015a. On the brink: micromammals from the latest Villanyian from Bıçakçı (Anatolia). Geological Journal 50 (3), 230-245.

Van den Hoek Ostende, L.W., Gardner, J.D., van Bennekom, L., Alçiçek, M.C., Murray, A., Wesselingh, F.P., Alçiçek, H., Tesakov, A., 2015b. Ericek, a new Pliocene vertebrate locality in the Çameli Basin (southwestern Anatolia, Turkey). Palaeobiodiversity and Palaeoenvironments 95 (3), 305-320.

Varol, B., Araz, H., Karadenizli, L., Kazanci, N., Seyitoglu, G., Sen, S., 2002. Sedimentology of the Miocene evaporitic succession in the north of Cankiri-Corum Basin, Central Anatolia, Turkey. Carbonates and Evaporites 17, 240-253.

Venczel, M., Sen, S., 1994. Pleistocene amphibians and reptiles from Emirkaya-2, Turkey. Herpetological Journal 4, 159-165.

Wilson, M., Tankut, A., Güleç, N., 1997. Tertiary volcanism of the Galatia province, northwest Central Anatolia, Turkey. Lithos 42, 105-121.

Zhang, Z.-Q., Kaakinen, A., Wang, L.-H., Liu, L.-P., Liu, Y., Fortelius, M., 2012. Middle Miocene ochotonids (Ochotonidae, Lagomorpha) from Damiao pliopithecid locality, Nei Mongol. Vertebrata PalAsiatica 50 (3), 281-292. 